AperTO - Archivio Istituzionale Open Access dell'Università di Torino

\title{
Switching behavior and the liberalization of the Italian electricity retail market. Logistic and mixed effect Bayesian estimations of consumer choice
}

This is a pre print version of the following article:

Original Citation:

Availability:

This version is available http://hdl.handle.net/2318/1692253

since 2019-02-20T09:38:10Z

Published version:

DOI:10.1016/j.enpol.2019.01.060

Terms of use:

Open Access

Anyone can freely access the full text of works made available as "Open Access". Works made available under a Creative Commons license can be used according to the terms and conditions of said license. Use of all other works requires consent of the right holder (author or publisher) if not exempted from copyright protection by the applicable law. 
Manuscript Number: JEPO-D-18-02597R1

Title: Switching behavior and the liberalization of the Italian electricity retail market. Logistic and mixed effect Bayesian estimations of consumer choice.

Article Type: Full length article

Section/Category: Energy Markets and Pricing

Keywords: Liberalized electricity markets; switching behavior; Bayesian mixed

Logit model; Local market heterogeneity

Corresponding Author: Professor Consuelo Rubina Nava,

Corresponding Author's Institution: University of Aosta Valley

First Author: Magda Fontana, PhD

Order of Authors: Magda Fontana, PhD; Martina Iori; Consuelo Rubina Nava

Abstract: The paper highlights the importance of both local effects and market structure in determining the switching decision in retail electricity markets, and also introduces a new definition of household as the bundle of features of its members. We apply a Bayesian mixed Logit model to analyze the switching behavior in the Italian electricity retail market. The data set includes social, demographic, geographic and economic information regarding 18,448 households and 37,217 individuals together with their opinions, expectations and choices regarding national services. Results show that heterogeneity in the geographic and social context of choice and in the household composition has a major impact on the significance and on the identification of switching determinants implying that there is no one-size-fits-all policy to encourage switching and that further efforts should be dedicated to the definition of an optimal scale of analysis. 
Dear Professor Jefferson,

We would like to thank the reviewers for their time and useful comments towards the improvement of our manuscript. We have made significant changes to the structure and flow of the paper that is now more focused on the novel bringing of our research. In more detail:

- The Abstract has been rewritten (Reviewer \#1 and \#4). It highlights research questions, results, data and methodology

- The Introduction has been shortened and more closely related to the research topic (Reviewer \#1).

- In the Background and Literature Review, with the aim of framing our contribution in the literature, we have included two tables that systematize the studies on determinants and their methodologies. Moreover, we have split the switching determinants in categories as asked by Reviewer \#4

- We have added Section 3 that states the research hypotheses (Reviewer \#4 and \#6).

- The description of the methodology has been shortened and made more accessible to a wider audience (Reviewer \#4). The 'technicalities" have been moved to Appendix B (Logit and Mixed Logit models). In addition, we have tried to illustrate more clearly the link between our research hypotheses and the methodological approach.

- The Discussion has been extended and there is more emphasis on the policy implications of our findings.

- Finally, a native English speaker has revised the manuscript (Reviewers \#5 and \#6).

We do hope that this improved version of the article is suitable for publication. Please find below the detailed response to the reviewers.

\section{Reviewer \#1: General comments.}

The paper provides an empirical analysis of the individual and household switching. How empirical findings may be used by governments or regulatory authorities to improve the results of the liberalisation process? More specifically, which measures the authors suggest to increase switching rates? Since switching is not an objective per se, how it relates with general policy aims? Indeed, one can argue that individuals and households can benefit from liberalisation even if they decide to not switch, but simply profiting from lower prices and better quality. I also suggest to focus policy implications on Italian case by referring to applied or planned measures, such as the abolition of the "maggior tutela" service.

$\rightarrow$ We have introduced a section (Section 8) dedicated to the discussion of the findings and to their policy implications. We are confident that with respect to the previous draft, the relationship between switching and liberalization is now clearer. In addition, the focus of the paper is now on switching and the benefits of liberalization in general are discussed only after the analysis (again Section 8 ) 
Specific comments

- The abstract should be summarise and improved. The current version is too general and does not clarify the results obtained.

$\rightarrow$ The abstract is now more focused on research questions, results, data and methodology.

- The introduction should be focused more on research questions and the rational behind the paper. I suggest the authors to focus more on geographical features of electricity markets explaining potential differences in local markets functioning, as well as on specificities of the Italian markets.

$\rightarrow$ The introduction has been shortened and is more 'straight to the point'. Thank you for the suggestion.

- It would be useful to give readers information about the current structure of the electricity tariffs for final consumers in order to fully understand the effective room for competition among retailers. In this respect, as noticed in note 1 , there seems to be a wide range of commercial offers as the difference between the maximum price is 22 per cent higher than the minimum.

$\rightarrow$ These data are obtained at the national level including the regulated sector that offers the lowest tariffs. In addition, as a relevant number of retailer operates at a local scale the 'best' tariffs are not available to all households. Moreover, the information that we report does not discriminate between retailers but is related to the contracts that can be offered by the same retailer. Unfortunately, we cannot draw any conclusion on the degree of competition from these figures.

- There is a growing literature on cultural determinants of energy and environmental behaviour that authors should be take into account in their literature review (see references below). - Recent changes in the Italian electricity have been analysed in many researches (see reference below).

$\rightarrow$ Thank you, we've found the references very useful especially for the discussion of the policy implications.

- I suggest the author to drastically summarise the description of the database (par. 3.1). I also suggest to cut the following sentence: " Discussion

of the historically and economic differences between these areas falls outside the scope of this paper, however few facts should be sufficient to highlight institutional heterogeneity. The (former kingdom of) Italy was born in 1861 from the unification of several kingdoms, states and duchies each of them characterized by different institutions and culture and experiencing various degree of social and economic development. The Kingdom of Sardinia, ruled by the Savoy was essentially a French court, whereas the Kingdom of Lombardy-Venetia was a crown land of the Austrian Empire. Central Italy was divided between the Papal State and the Grand Duchy of Tuscany that, as a continuation of the Duchy of Florence, dated back to the second half of XVI century and since then was a thriving centre for commerce. Finally, Southern Italy was ruled by the Kingdom of the Two Sicilies held by a Spanish cadet branch of the 
Bourbons. The legacy of history is still strong in the Italian nation.

For instance, in Trentino-Alto Adige a conspicuous part of the population speaks German. In Sicily, the remains of the large estate conditioned the economy until very recent years (Liberto and Sideri, 2015)."

$\rightarrow$ The sentence has been deleted and the data description has been shortened

- It is not clear to me if the concentration ratio actually refers to the retail segment. Please specify.

$\rightarrow$ The concentration rate refers to the retail segment (see Section 6.1).

- What the authors mean by "ancillary services"? Note that the term of "ancillary services" is used in a rather different context (electricity generation and system balancing).

$\rightarrow$ Thank you for having pointed this out, the term has been substituted with "accessory".

Suggested references

- Quaglione D., Cassetta E., Crociata A., Sarra A. (2017), Exploring additional determinants of energy-saving behaviour: The influence of individuals' participation in cultural activities.

ENERGY POLICY, Vol. 108, pp. 503-511. doi: 10.1016/j.enpol.2017.06.030

- Monarca U., Cassetta E., Sarra A., Pozzi C. (2015), Integrating renewable energy sources into electricity markets: Power system operation, resource adequacy and market design. ECONOMICS AND POLICY OF ENERGY AND THE ENVIRONMENT, 2, pp. 149-166. doi: 10.3280/EFE2015-002010

Reviewer \#2: The paper provides some interesting results on the analysis of switching rates in the retail electricity market in Italy, exploring the role of various determinants (among others gender, education, composition of households, the geographic area, ... ). The paper contributes to the literature on the topic on two aspects: (i) is an original application of a statistical econometric methodology (hierarchical bayesian choice model) within this field. The second area of originality is in the findings that show that for some drivers there are region-specific patterns.

\section{Remarks:}

1. In discussing the policy implications, the paper (also in the highlights) suggests that the "Policy should account for variation in switching determinants across regions". The link with the econometric result is clear, but in terms of policy implications the author(s) should try, in the paper, to elaborate further such finding.

$\rightarrow$ We have introduced a new section dedicated to the discussion of the main findings and to their policy implications (Section 8). We are confident that in the new version the implications of our work are stated more clearly.

2. The comparison in the precision (size of credibility/confidence interval) between 
classical and the multilevel Bayesian approach is hidden (the reference to figure 6 and 7 are just in a foot note, sending the reader to the appendix. This is a main methodological advancement from a standard logit model to an analysis that allows to integrate individual and household level information in the same model.

$\rightarrow$ The comparison between the classical and the Bayesian approaches has been introduced in the methodology section together with the related figures.

3. The Bayesian estimation with multilevel is applied to other fields? Some references may help understanding and deepen if the approach is popular to other areas (stated preference analyses?)

$\rightarrow$ References to previous works can be found in footnote number 1 and 2:

"The MLM, with fixed and random effects, is first introduced and applied as the hedonic demand model in Cardell, Dunbar (1980) and Boyd, Mellman (1980). Only at the end of the last century, it becomes popular in theoretical and applied economics, especially to model transport demands (Bolduc, Ben-Akiva, 1996; Brownstone, Train, 1998)."

"Theoretical contributions on the Bayesian mixed Logit model can be found in the econometric and statistical literature (see, among the others, for a comprehensive review Train, 2001; Hensher, Greene, 2003). Empirical applications are, however, still limited. For instance, in Balcombe et al. (2009) the Bayesian MLM is used to estimate the willingness-to-pay, in Choi et al. (2013) to estimate PC table demand, while Rigby, Burton (2006) describes food attribute preferences. Instead, for a multivariate application to author identification see Madigan et al. (2005)"

4. Do the results allow deriving an overall assessment of the Italian market according to the objectives of the EU third energy package? The final statement may implicitly suggest that liberalisation success depends from switching rate only. It is not straightforward to link the exploration of its determinants to the impacts on consumer surplus, market adequacy and stimulus to innovation. Is the Italian case peculiar? Why? Expanding interpretation could sensibly improve the comments to the results.

$\rightarrow$ We have introduced a new section dedicated to the discussion of the findings and to their policy implications (Section 8). We are confident that with respect to the previous version the relationship between switching and liberalization is now clearer. In addition, the focus of the paper is now on the switching and benefits of the liberalization in general are discussed only after the analysis (again Section 8)

5. Carefully check the references: exact spelling of authors' name as Moshe Ben-Akiva

$\rightarrow$ Thank you for having pointed this out, we have corrected and checked all references.

6. In table 7 at the row corresponding to the McFadden $\mathrm{R} 2$ there is a number (7) between the first and the second column. Is it a typo?

$\rightarrow$ It was the page number, we have corrected it.

7. The suppliers in Italy tend to have a more local scale. Nationwide suppliers in Italy 
covers, according to CEERS data only the $9 \%$ out of the total number of suppliers. Geographical differences in switching may eventually be induced by features and/or practices of suppliers/retailers? On the differences among different EU countries monitoring reports are provided by CEER: (https://www.ceer.eu/documents/104400/-/-/56216063-66c8-0469-7aa09f321b196f9f).

$\rightarrow$ Unfortunately we cannot precisely identify this aspect, which is surely relevant, in our data set. It is loosely captured in what we call "context" and it is worth investigating on more finegrained data that we hope to obtain in the future.

8. The final part of the conclusions may implicitly suggest that liberalisation success depends from switching rate only. Switching rate values, and the exploration of its determinants do not say much on the impacts on consumer surplus, market adequacy and stimulus to innovation. I would suggest to reinforce supporting with arguments by references to further empirical evidence to other studies or to avoid generic statements.

\section{$\rightarrow$ See response to remarks 1 and 4}

Reviewer \#3: The paper makes an econometric analysis of the switching rate of the Italian electricity market. It takes into account a series of variables and evaluates the effect of liberalization. The work is valid as it considers a large amount of consumers. I wonder if some more factors could probably be also considered: the fact that in regions with special administration (Valle D'Aosta and Alto Adige) consumers have special prices staying with the local supplier could probably affect the results (in Valle D'Aosta CVA gives electricity almost for free).

$\rightarrow$ Thank you for the suggestion, unfortunately we do not have prices in our data. However, we believe that the focus of our work is to determine the context of choice (and its heterogeneity). We believe that the practices that you mention are captured by the inclusion of local effects.

Reviewer \#4: Overall, this is a relevant and original contribution to the field of consumer's behavior and energy economics. This paper exploits a large database on 37217 individuals in Italy (ADL: Aspects of Daily Life Survey) to analyze the switching behaviors in 2013 in the electricity market (post-liberalization). The methodology (Bayesian multinomial mixed logit) is new and interesting. I see an important contribution in this manuscript as far as the paper applies a new methodology to account for individual characteristics and show a substantial degree of heterogeneity at the regional level. The analysis, bringing together individual and regional determinants, has highly relevant policy implications as explained in the conclusions of the paper.

My main suggestions are (1) to re-organize the paper (2) to build a more solid theoretical section.

1. Section 2 is interesting and detailed. It could be shortened and possibly divided into sub-sections by switching determinants. One possibility is, first, to mirror the empirical part of the paper and to describe the available results distinguishing individual, household and market variables and, secondly to discuss the impact of the switching 
behavior of the economic determinants, service characteristics and information. Geographical variables are very important in the paper and the literature review does not analyze this point. Has this point been addressed by previous papers? If this is the first paper that discusses regional heterogeneity in depth, this should be put at the forefront. Section 2 should finish at page 5 line 38.

$\rightarrow$ We have restructured the paper as you suggested, thank you for helping us in making our points clearer.

In general:

- the Abstract has been rewritten. It highlights research questions, results, data and methodology;

- the Introduction has been shortened and more closely related to the research topic;

- in the Background and Literature Review, with the aim of framing our contribution in the literature, we have included two tables (1 and 8) that systematize the studies on switching determinants and their methodologies;

- moreover, we have split the switching determinants in categories;

- we have added Section 3 that explicates the research hypotheses;

- the description of Data now precedes the figures;

- the description of the methodology has been shortened and made more accessible to a wider audience;

- the 'technicalities" have been moved to Appendix B (Logit and Mixed Logit models) and C (The parametric Bayesian MLM);

- $\quad$ in addition, we have tried to illustrate more clearly the link between our research hypotheses and the methodological approach;

- the Discussion has been extended and there is more emphasis on the policy implications of our findings.

2. I would move Section 3.2 - where the author(s) describe the Italian electricity market - right after Section 2 . I suggest to discuss immediately the Italian institutional system and the Italian market and I would live the Figures for the data section because data sources are not yet described at this point.

$\rightarrow$ The section on the Italian market has been shortened: in the new draft it describes the institutional setting ad report some data released by the Authority (Section 5). The Figures have been moved in the data Section that immediately follows (Section 6)

3. In this paper there is a scant discussion of the theoretical hypotheses. These are confined to a couple of paragraphs between line 39 in page 5 and line 16 at page 6 . I suggest to make this part more robust and build a dedicated section in which the research hypotheses are specified more clearly. I would avoid lingering on broad issues related to the agent rationality (e.g. line 10 and 11) but rather I suggest to simply explain the main relevant hypotheses tested in the paper. The hypothesis can be interestingly tailored on the Italian institutional context described in section 3.2 (This is why I suggest to anticipate it). The historical discussion in the data section at page 7 (line 38-55) can be integrated here in a footnote.

$\rightarrow$ Thank you for this suggestion. The research hypotheses are now illustrated and discussed in Section 3.

4. This theoretical section should also include the final reduced model with the 
proposed explanatory variables. Now this is partly done between line 44 and line 55 in Section 5. This part should be expanded and linked to the theoretical discussion.

$\rightarrow$ The reduced model is introduced in Section 3, after the research hypotheses

5. Once the theoretical part is specified more neatly, the discussion of the required methodology can immediately follow. The paper already explains the key elements of the methodology. It would however benefit from a clearer link between the theoretical questions and the methodology adopted. It can be simplified and some details can be added to the Appendix. It is very interesting and relevant to exploit data at the individual level. However it is important here to clarify the problems of the simple standard logit models (e.g. individuals and household heterogeneity, precision, model performance) and the advantages of the proposed Bayesian multinomial mixed logit. This journal appreciates rigorous statistical analysis but the methodological improvement should be understandable also to a larger audience. Footnote 17 can be canceled and the discussion of the biases can be included in the main text in the methodology section.

$\rightarrow$ According to this suggestion, we have rewritten the methodological section, moving equations, statistical details and formal model presentations to Appendix $B$ and $C$. We also clarify the link between theoretical and methodological issues, starting from the nature of the response variable and discussing the level at which different covariates are measured.

6. The data should be introduced and described after the methodology.

$\rightarrow$ As suggested, the data are introduced after the methodology and a (shortened) description of the Italian market.

Minor comments.

1. The abstract should be rewritten and shortened to sharpen the focus on the data, methodology and main results.

$\rightarrow$ Done

2. I do not think the author(s) should worry about whether there is agreement or not between theoretical models to describe consumer choice (line 35, page 2 and first line page 4)

$\rightarrow$ Done

3. Check that all the acronyms are explained in particular in the methodology section.

$\rightarrow$ Thank you for pointing this out, we've checked the acronyms.

Reviewer \#5: The paper deals with an important and interesting topic. Literature, data and methodology are well documented and well explained. The exposition is clear and concise as it should be (except for the methodological part, which is a bit long, but it is necessary to explain everything). Overall, I think that the paper is very good. There are 
only few points that I would like to make.

First and foremost, English. The grammar of the paper needs a careful revision. There are many typos; I started to correct them, but since there are a lot, I ceased to correct because it would have meant too much work for me. The most common errors that I found are missing "s" in the third person (singular of course), missing "ing" for some verbs and missing (or redundant) commas here and there. However, there are many other. This needs a careful revision from an expert. Also, in the beginning of the paper (and abstract), I think it is more correct to say "exchanges take place" instead of "exchange takes place"

$\rightarrow$ A native English speaker has revised the manuscript.

2. I found the historical paragraph in section 3.1 redundant and off topic. I suggest to eliminate the whole paragraph from "The (former kingdom of)..." to "(Liberto and Sideri 2015)". I think it is sufficient to simply state territorial heterogeneity, as a matter of fact.

$\rightarrow$ The paragraph has been deleted.

3. you use American English, but in section 3.1 you wrote "behaviour", which is British English. Check the consistency of the language you use.

$\rightarrow$ A native English speaker has revised the manuscript also in this direction.

4. The name of the Italian Energy Regulator is ARERA, not AEEGSI anymore. Check and correct this

$\rightarrow$ Thank you for pointing this out. The name has been corrected.

5. In section 3.2 "Dlgs 79/99" does not mean anything for a non Italian reader. Write it in extensive form.

$\rightarrow$ Done

6. Why do you model stochastic components as a Gumbel distribution? Could you provide a little explanation, even in a footnote?

$\rightarrow$ See the explanation in Appendix A: "We assume standard Gumbel independent and identically distributed (i.i.d.) errors, derived as a particular parametrisation of the generalized extreme value distribution. This assumption allows to derive a Logit model starting from the Random Utility theory (see, among the others, Train, 2003). Given the heavy tails of the Gumbel distribution, we are able to better model household choices. Its use is, indeed, close to assuming independent normal errors, except that the heavy tails allow more robust analyses taking into account a "slightly more aberrant behavior than the normal" (Train, 2003, p. 39), crucial for this empirical application."

7. Abstract and the first part of the introduction are exactly the same. I think that the 
abstract should be rewritten, being more concise (especially the first half) and more to the point.

$\rightarrow$ The Abstract has been now rewritten as follow: "The paper highlights the importance of both local effects and market structure in determining the switching decision in retail electricity markets, and also introduces a new definition of household as the bundle of features of all its members. We apply a Bayesian mixed Logit model to analyze the switching behavior in the Italian electricity retail market. The data set includes social, demographic, geographic and economic information regarding 18,448 households and 37,217 individuals together with their opinions, expectations and choices regarding national services.

Results show that heterogeneity in the geographic and social context of choice and in the household composition has a major impact on the significance and on the identification of switching determinants implying that there is no one-size-fits-all policy to encourage switching and that further efforts should be dedicated to the definition of an optimal scale of analysis."

8. Policy implications (but also elsewhere): you talk of "deregulation", but as you yourself say, the Italian market does still have, de facto, a regulated tariff which the majority of consumers pay. I think that this aspect should be more stressed in the conclusions of the paper and that it may be a valid explanation for the low propensity for switching. Furthermore, you say that, on average, consumers pay less with the regulated tariff. This fact in Italy is common knowledge, even though it is not necessarily true anymore (by the way, there is an update of the ARERA report you cite, you can find it here: https://www.arera.it/it/docs/17/801-17.htm), and this generalised consumers' "mistrust" towards the free market could also explain the low propensity to switch for Italian consumers.

$\rightarrow$ We discuss the 'hybrid' nature of the Italian market in Section 8. We have included some information from the new report in Section 5 footnotes 12 and 13.

9. Check the references in the captions of figures 5 and 6

$\rightarrow$ Done

10. Are $A$ and $B$ in page 18 appendixes? If so, they are not cited anywhere and there is not even a title.

$\rightarrow$ Appendixes have titles and are positioned after the references.

Reviewer \#6: My recommendation for Energy Policy's editor is that this article should be accepted for publication in the journal with revisions.

The main reason for this is the compatibility with Energy Policy's current publishing interests

In my opinion the article is a good policy article.

The policy contents are widespread in almost all the paragraphs describing the switching behaviour in the Italian electricity market.

The highlights are adequate.

- Authors should clearly indicate a policy implication in the abstract and clarify the purpose of the research. 
$\rightarrow$ The abstract has been rewritten and now contains our main policy implication, i.e. that policy should account for heterogeneity.

- It is opportune to indicate in the introduction in a clear way the research questions and any hypotheses to be demonstrated.

$\rightarrow$ We have added Section 3 where the research hypotheses are stated. The hypotheses are also briefly sketched in the Introduction.

- The paper is shown in the abstract, in the introduction and in the conclusions as the first that reflects on the behavior of switching in the Italian electricity market. I do not agree only partially with such statements. In this sense, the authors have to indicate at least in the literature review how their paper differs and what additional contribution it provides compared to other papers on similar subjects, including the following papers: Iovino, F. (2012) "Le scelte delle politiche di marketing delle imprese energetiche" and Iovino, F. (2015), "Relationship marketing by energy companies".

$\rightarrow$ We have removed the statement and included the suggested references. Thank you for pointing this out. The literature has been further analyzed by introducing Tables 1 and 8.

- The authors should correct the date of conclusion of the Italian regulated market on p. 8 line 41.

$\rightarrow$ Done

- The results section and discussion should be expanded. In the conclusions the authors have to indicate more clearly and more explicitly the general political implications for all energy markets, in particular the European ones deriving from the Italian case

$\rightarrow$ The discussion of results is now articulated in two sections. Section 7 comments mainly on the interpretation and significance of determinants, whereas Section 8 frames the findings in a broader policy framework and discusses the research hypotheses.

- There are typos in sentences that should be corrected.

$\rightarrow$ A native English speaker has revised the manuscript.

The authors should indicate the new name of the AEEGSI.

$\rightarrow$ Done

- Furthermore, they should indicate the references according to the style of the journal.

$\rightarrow$ Done

- Figures and tables highlight results well and support conclusions. However, the source of the individual tables and figures have to be indicated even if they are their 
own personal elaborations and indicate in the description of fig. 5 and 6 the tables to which they refer.

$\rightarrow$ Thank you for pointing this out. The source of data is now suitably indicated. 
Switching behavior in the Italian electricity retail market: Logistic and mixed effect Bayesian estimations of consumer choice.

\begin{abstract}
Keywords Liberalized electricity markets - Switching behavior - Bayesian mixed Logit model · Local market heterogeneity
\end{abstract}

JEL Classification L43 · D02 · C11 


\section{Introduction}

The rate of switching between providers in the electricity retail market provides information on the participation of consumers in the market activities and on the effects of liberalization (CEER, 2015; Yang, 2014). The study of switching determinants is, therefore, important to both policy making and policy evaluation. The paper adds to the vast literature that investigates the determinants of switching behavior (see Section 2) by pointing out three aspects that are overlooked in the existing analyses.

Firstly, we introduce a new definition of household. We show that, although switching affects the household as a whole, the determinants of this choice depend on the characteristics of the individuals that belong to the same household (e.g. age, working status, education). To characterize the household in terms of the features of all its components we adopt, for the first time in this literature (Table 8 in Appendix A), a parametric Bayesian mixed Logit model. Secondly, we consider regional heterogeneity as a factor that influences switching determinants. Finally, we take into account the choice context by introducing information on the structure of the market.

We analyze the switching choice in the Italian retail electricity market, several features of which contribute to make the investigation interesting. The market is hybrid in that the free market coexists with a regulated one and the country exhibits a pronounced regional economic and social heterogeneity. Our analysis exploits the Aspects of Daily Life survey (ADL) carried out in 2014 by the Italian National Institute of Statistics (ISTAT). We observe social, demographic, geographic and economic information regarding 18,448 households and 37,217 individuals.

Results show that the identification of the switching determinants depends on the definition of the household. By including the features of all the household members, we find that the access to the Internet positively affects the switching probability and that the concentration rate of the market has a negative impact on the switching activities. Moreover, we find significant local effects: the determinants of switching behavior vary according to the household's macro-region of residence. We conclude that the instruments deployed to achieve an efficient liberalized electricity market (also by promoting retailer switching) should be sufficiently differentiated so as to reflect the countries' distinct situation and their within-country heterogeneity.

The paper is structured as follows: Section 2 reviews the literature on the topic. Section 3 
illustrates the research hypotheses and Section 4 expounds the methodology. Section 5 briefly describes the Italian retail electricity market while Section 6 introduces data and variables. Section 7 presents the results, Section 8 discusses and concludes.

\section{Background and Literature Review}

Switching behavior has been extensively studied from different perspectives, from marketing (Keaveney, 1995; Peng and Wang, 2006) to industrial organization (Joskow, 2008). This section identifies the main switching determinants and frames our contribution within the literature (Table 1).

Electricity Price The price of electricity and the associated savings are, in principle, decisive factors in switching decisions. Indeed, it is natural to think that, since electricity is an undifferentiated good, the only difference perceived by consumers is price (Gamble et al., 2009). However, the high share of transmission costs and taxes generally leaves the retailer little margin for price competition. It follows that price differences among retailers are often negligible and savings from switching are very small in comparison to the income of the average household (Sirin and Gonul, 2016). Consequently, incentives to undertake costly searches for better contracts and cheaper tariffs are low (Giulietti et al., 2014; Klemperer, 1995; Wieringa and Verhoef, 2007).

There is additional evidence showing that households pay little attention to relative prices or tend to underreact to price changes (He and Reiner, 2015). For instance, Vesterberg (2018), in exploring switching between fixed and variable-price electricity contracts, finds little reaction to price changes. Finally, switching costs are negatively correlated with switching (Sirin and Gonul, 2016; Wieringa and Verhoef, 2007). He and Reiner (2015) show that consumers may tolerate perceived high prices offered by the incumbent when switching costs are perceived as high. Evidence on the impact of the economic status, mainly income, is mixed. Ek and Söderholm (2008), Gamble et al. (2009), and Rowlands et al. (2004) find that households with a higher income tend to switch more. Interestingly, Giulietti et al. (2005) and Fontana et al. (2018) find that lower income households tend to consider switching more than households with higher income but are not as likely to switch as the latter.

Individual Rationality Doubts have been cast on individual rationality in making the switching decision. Wilson and Waddams Price (2010) find that a group of consumers, who 
declares that a switching decision is uniquely driven by price reasons, is nevertheless unable to fully appropriate the available gains (see also Annala et al., 2013). Limitations to rationality have also been evidenced by Wieringa and Verhoef (2007). According to their analysis, an increase in the number of available contracts results in a reduction of the switching rate due to difficulties in ranking options.

Demographic features Education is often found to have a positive effect on switching (Ek and Söderholm, 2008; He and Reiner, 2015; McDaniel and Groothuis, 2012; Rowlands et al., 2004). Men are more likely to switch than women according to Gamble et al. (2009) and the activity in the market decreases with age in the findings of Rowlands et al. (2004) and Fontana et al. (2018), whereas He and Reiner (2015) show that both gender and age are irrelevant to switching.

Psychological traits Psychological traits, such as loyalty to the current retailer (often the previous monopolist), are also found to have a negative effect on active behavior (Daglish, 2016; Gamble et al., 2009; Szymanski and Henard, 2001). Similarly, risk aversion also negatively impacts the switching behavior (Schleich et al., 2017; Sirin and Gonul, 2016). Switching in other markets seems to reduce the effect of psychological and informational barriers (Fontana et al., 2018; Giulietti et al., 2014; Wirtz et al., 2014) and this has the potential to encourage the switch in the electricity market, since consumers learn how to compare and choose better offers. Similarly, consumers that change retailers in other utilities and are satisfied with their choice are more likely to switch in the electricity market as well (McDaniel and Groothuis, 2012). On the contrary, the hypothesis that shifting retailer in various markets would entail a process of learning how to compare offers finds no confirmation in Defeuilley (2009). Features such as the satisfaction with the service and a high quality customer relationship management have a negative effect on the probability of switching (Wieringa and Verhoef, 2007; Yang, 2014) while service failures have a positive effect (Keaveney, 1995).

Quality and quantity of information The quality and quantity of information about the service is considered a factor encouraging switching: a higher amount of information is commonly associated with more active and efficient consumers (Flores and Waddams Price, 2018; Fontana et al., 2018; Gärling et al., 2008; Hortaçsu et al., 2015; Loi and Le Ng, 2018) and vice-versa (He and Reiner, 2015).

Other determinants Studies on Japan (Shin and Managi, 2017), Sweden (Gärling et al., 2008) and Germany (Sauthoff et al., 2017) highlighted that preferences for green energy have a 
positive effect on switching. Finally, political events are found to impact on switching. He and Reiner (2015), in a survey on British households, find that voting intention is highly correlated with switching behavior. Namely, Labour voters were the most likely to switch out of all political party supporters. This result is possibly explained by the emphasis that the Labour party was giving to the issue of energy bills at the time in which the data were collected (2013-2014).

Table 1: Here

Table 1 shows that our analysis adds two categories of determinants - Local effects and Market structure - to previous analyses of switching behavior. The hypothesis that differences in market and institutional frameworks should be included in the study of energy markets was set forth by Monarca et al. (2015) in the context of the integration of renewable energy sources into electricity markets. This hypothesis is easily extended to switching behavior and to the related policy implication that a "one-size-fits-all" policy approach may work.

\section{Research hypotheses}

While the literature mainly focuses on the features of the decision makers (Table 1), we argue that the structure of the market also affects the switching decision. For instance, the number of retailers and their market shares define the set of opportunities available to consumers. Moreover, a more concentrated market results in a weakest competition and, therefore, in a lower level of benefits that derive from switching. Hence, we argue that a higher market concentration should result in lower switching rates (Hypothesis I).

Studies on switching are commonly conducted at the national or local level (Table 8 in Appendix A), however the characterization of the institutional, geographic and cultural context of choice is not explicitly considered among switching determinants. We maintain that the place of residence of the household (e.g. city, region, macro-region) embeds the local context features (habits, economic development, provision of services) and, as a consequence, affects switching. It follows that, if the context of choice is heterogeneous, the switching determinants might vary even within the same country (Hypothesis II).

In the literature (Table 8 in Appendix A), the unit of analysis is either the household characterized by the attributes of the contact person (hereafter, HCP) or the individual without references to the family (hereafter, IN). We claim that the decision to switch is determined by the by the characteristics of the household members that, therefore, should be explicitly included 
in the analyses (Hypothesis III).

In order to test these hypotheses, we explicit an econometric model for the electricity retailer switching probability with individual and household specific covariates. This approach differs from the extant literature since it attributes each individual to his/her household (hereafter, $\mathrm{HH}$ ). We consider economic, demographic, and informational variables with the addition of a local index of market concentration (Hypothesis I and II), a macro-region and a size of the municipality of household residence (Hypothesis II). In order to corroborate our hypotheses, we compare estimates with local effects with the ones at the country level, while estimates with HH are compared with the ones with HCP.

We estimate the switching probability $(j=1)$ of individual $r$ in household $k$, namely $\pi_{k r}=$ $P_{k r}\left(j=1 \mid \boldsymbol{x}_{k r}\right)$, according to covariates $\boldsymbol{x}_{k r}=[\boldsymbol{i} \boldsymbol{h} \boldsymbol{m}]_{k r}$ through the following model:

$$
\operatorname{logit}\left(\pi_{k r}\right)=\alpha+\boldsymbol{x}_{k r}^{\prime} \boldsymbol{\beta}+u=\alpha+\boldsymbol{i}^{\prime} \boldsymbol{\beta}^{\boldsymbol{i}}+\boldsymbol{h}^{\prime} \boldsymbol{\beta}^{\boldsymbol{h}}+\boldsymbol{m}^{\prime} \boldsymbol{\beta}^{\boldsymbol{m}}+u
$$

where $\boldsymbol{i}, \boldsymbol{h}, \boldsymbol{m}$ identify, respectively, the vectors of individual, household and market covariates characterising individual $r$ in household $k$. Similarly, $\boldsymbol{\beta}^{\boldsymbol{i}}, \boldsymbol{\beta}^{\boldsymbol{h}}, \boldsymbol{\beta}^{\boldsymbol{m}}$ are the associated vectors of fixed effects, while $u$ is a household $k$ random intercept.

The next section expounds the adopted methodology.

\section{Methodology}

We represent the household decision as a binary choice: switch or non-switch. Hence, the household response is a random variable equal to 1 if the household switches and equal to 0 if it does not switch.

A closed form for the choice probability, obtained considering a Logit model (Luce and Suppes, 1965; McFadden, 1974), is widely used in the literature to model the household switching decision (Table 8 in Appendix A). Its implementation allows us to align with the previous findings and to compare them with our approach. This fixed effects econometric model explains switching behavior at the household level when only one of its members is considered (HCP).

However, our hypothesis is that switching is a household decision and that the household should be characterized as the bundle of features of its members (HH). To this purpose, we use individual level data to extend the Logit model. It is worth noting that it is not possible to obtain Logit unbiased estimates considering directly all the individuals (IN) as autonomous 
decision makers, since they share the same household decision. Therefore, we add a random grouping effect, formally a household intercept, to aggregate members of the same family and we adopt the more general mixed Logit model (MLM). In more detail, the HH is characterized by the individuals that share the same household id. The latter is used as the grouping variable to cluster errors and to define a specific random intercept (see Appendix B for specification details) ${ }^{1}$

The mixed Logit model is considered a flexible model that approximates any random utility model (McFadden and Train, 2000) and that overcomes the main limitations of the standard Logit model (e.g. it allows for random taste variation, unrestricted substitution patterns, and correlation in unobserved factors; see Train, 2003). We reinterpret the mixed Logit model in a Bayesian framework to exploit the presence of random effects and to overcome the limitations of the frequentist approach. We consider a parametric Bayesian MLM (Goldstein, 2011), as a particular case of the more general Bayesian multinomial mixed Logit model proposed in Nava et al. (2016). ${ }^{2}$

With respect to the standard frequentist approach, that directly estimates model parameters, Bayesian methods assign a probability distribution to such parameters, namely the prior distribution, which embodies the available prior information. After data observation (modeled via the likelihood function), the updated prior knowledge results in a posterior distribution on which the Bayesian estimations are obtained (see Appendix C for further details on Bayesian methods). Therefore, while in the frequentist approach parameters are considered unknown but are fixed, in the Bayesian framework they are treated as random variables. The Bayesian approach has several desirable properties. Firstly, a Bayesian MLM increases flexibility, computational tractability and estimation accuracy with respect to the classic MLM, even if it does not allow a formal distinction between fixed and random effects since they are all endowed with suitable prior distributions. ${ }^{3}$ Secondly, estimators consistency and efficiency are attained under

\footnotetext{
${ }^{1}$ The MLM, with fixed and random effects, was first introduced and applied as the hedonic demand model in Cardell and Dunbar (1980) and Boyd and Mellman (1980). Only at the end of the last century it became popular in theoretical and applied economics, especially to model transport demand (Bolduc and Ben-Akiva, 1996; Brownstone and Train, 1998).

${ }^{2}$ Theoretical contributions on the Bayesian mixed Logit model can be found in the econometric and statistical literature (see, among the others, for a comprehensive review Hensher and Greene, 2003; Train, 2001). Empirical applications are, however, still limited. For instance, in Balcombe et al. (2009) the Bayesian MLM is used to estimate the willingness-to-pay, in Choi et al. (2013) to estimate PC table demand, while in Rigby and Burton Rigby and Burton (2006) to describe food attribute preferences. For a multivariate application to author identification see Madigan et al. (2005).

${ }^{3}$ To the best of our knowledge, Nava et al. (2016) is the first application which compares Bayesian and classical estimations in an extension of the MLM. Alternatively, random coefficients can be considered as a part of the utility error component, inducing correlations among alternative utilities.
} 
milder conditions. Thirdly, the (quasi) complete separation issue ${ }^{4}$ that often occurs in discrete choice models when random effects with a high number of levels (e.g. the household id) are included $^{5}$, is bypassed via the parameter priors elicitation. ${ }^{6}$

Specifically, the adopted Bayesian MLM assumes (multivariate) normal prior distributions for fixed and random effect model parameters. We enrich this hierarchy (Goldstein, 2011) by assigning an Inverse-Wishart (IW) prior distribution to the random effect covariance matrix. ${ }^{7}$ We select non-informative priors for all model parameters, with a large variance to reflect the relative lack of confidence about the mean assumed for the fixed and random effect priors (Finch et al., 2014). However, sampling from the resulting posterior distribution (eq. (3) in Appendix C) under these assumptions and obtaining marginal posterior distributions require further techniques. Thus, our estimations are based on the Markov Chain Monte Carlo (MCMC) method with a block Gibbs sampler algorithm (Casella and George, 1992), used in the Bayesian inference to update model parameters with a level of efficiency and computation tractability that is higher than the general Metropolis-Hastings algorithm (Hadfield, 2010). The block Gibbs sampler easily approximates the properties of the marginal posterior distributions by sampling from the conditional posterior distribution of each model parameter (eq. (3) in Appendix C) at the cost of a substantial increase in computing time.

Finally, model selection is done via the Akaike Information Criterion (AIC), in the frequentist framework, and via the Deviance Information Criterion (DIC), an approximation of a penalized loss function for a given deviance, in the Bayesian one. Formally, the DIC is a generalization of the $\mathrm{AIC}$ and it is used when MCMC simulations are required, as in this case. As in the AIC, the DIC minimum value signals the model with the best performance.

\footnotetext{
${ }^{4}$ Quasi complete separation issue results in the non-convergence of the Newton Raphson method in MLM estimates (Cox, 1989)

${ }^{5}$ Allison (2008), Altman et al. (2003), and Lesaffre and Albert (1989)

${ }^{6}$ Note that in any logistic regression model the log-likelihood function is globally concave, therefore the function can have at most one global maximum. Even if the logistic regression model has no local maxima issue due to a globally concave likelihood function (Amemiya, 1985), it might still happen that the latter has no maximum. This occurs when the choice probability is nearly perfectly predicted by a covariate or a linear combination of covariates (Webb et al., 2004). In other words, this often results in a complete or quasi-complete separation problem, implying that the maximum likelihood estimate does not exist. This problem, that is common to a wide range of empirical analyses based on a binary response variable, cannot be solved by increasing the number of iterations or by arbitrarily remove predictors to obtain an identifiable model (Zorn, 2005).

${ }^{7}$ Even if some other less informative priors than the IW can be considered (see, e.g. McCulloch and Rossi, 2000), the selection of an IW satisfactorily deals with complete separation problems while preserving invariance principles and, therefore, reducing estimation complexity. Moreover, such a prior is a multivariate generalization of the scale inverse- $\chi^{2}$ distribution (Gelman et al., 2014) and allows to exploit the conjugate normal-inverseWishart prior distribution.
} 


\section{Switching behavior in the Italian electricity market}

We apply this econometric model to the analysis of switching in the Italian retail electricity market. In accordance with the EU energy directives ${ }^{8}$ Italy began electricity-market liberalization in 1999 (Legislative Decree 1999, n. $79^{9}$ ), with the progressive unbundling of its national vertically integrated monopoly (Enel) and the consequent development of competitive wholesale and retail markets.

The process was completed with the deregulation of the retail market for domestic consumers, inaugurated on $1^{\text {st }}$ July 2007 and subjected to temporary regulation until $1^{\text {st }}$ July 2020 (the deadline was initially set to $1^{\text {st }}$ July 2019 by the Law $4^{\text {th }}$ August 2017, n. $124^{10}$ and then postponed by the Law $25^{\text {th }}$ July 2018, n. $91^{11}$ ). Under temporary regulation, domestic consumers may opt for a supplier on the free market or for a national electricity contract, the so-called "maggior tutela", regulated by the Italian regulatory authority for energy, networks and environment (Autorità di Regolazione per Energia Reti e Ambiente, ARERA ${ }^{12}$ ). In this kind of contracts electricity is often supplied by the local distributor system operator (DSO) that acts as a local monopolist. Tariffs depend on the fluctuations in the wholesale markets and are updated quarterly by the energy regulatory agency. Customers that do not take action are assigned to the regulated service that, in 2013 , still included $71.2 \%$ of domestic consumers.

As for the supply side of the market, the number of operators has been growing since 2007. The number of active groups rose from 219 in 2012 to 260 in 2013. For what concerns the number of retailers, 136 subjects operate on the regulated market, 3 in the safeguarded categories market, and 336 in the free market. With respect to 2012 the total number of operators has grown by 50 units. ${ }^{13}$ In 2013 , the main operator controlled about half of market sales, and the first three operators (CR3) delivered 72.4\% of energy volumes (AEEGSI, 2015). ${ }^{14}$

Domestic households that have opted for the free market pay a price higher than the one they would pay on the regulated market, with an increase that varies from $15 \%$ to $20 \%$ (with

\footnotetext{
${ }^{8}$ First Package, 1996: Directive 96/92/EC; Second Package, 2003: Directive 2003/54/EC; Third Package, 2009: Directive 2009/72/EC.

${ }^{9}$ http://www.camera.it/parlam/leggi/deleghe/99079dl.htm

${ }^{10} \mathrm{http}: / /$ www.gazzettaufficiale.it/eli/id/2017/08/14/17G00140/sg

${ }^{11}$ http://www.gazzettaufficiale.it/eli/id/2018/09/21/18G00134/sg

${ }^{12}$ Previously named AEEGSI (Autorità per l'Energia Elettrica il Gas e il Sistema Idrico), until $27^{\text {th }}$ December 2017. Documents published by the authority before 2017 are therefore referenced as AEEGSI.

${ }^{13}$ All the new entrants operate on the free market (AEEGSI, 2014). In 2016 the number of active groups was 373 (ARERA, 2017).

${ }^{14}$ The Herfindahl index is 2810 (AEEGSI, 2014). In 2016 the concentration rate was 69.9\% (ARERA, 2017). For a comparison with the other European markets see CEER (2017).
} 
reference to procurement costs only). This is in line with the findings of studies that report that households remain largely unaffected by the liberalization of retail markets or face higher power rates (Concettini and Créti, 2013; Defeuilley, 2009; Ghazvini et al., 2016; Joskow, 2000; Steiner, 2004). ${ }^{15}$ Higher energy prices cannot be explained solely by the provision of accessory services, since there is no conclusive evidence on the diffusion of new services especially for domestic consumers (Fehr and Hansen, 2010). In Italy, for 2013, the official comparison tool (TrovaOfferte ${ }^{16}$ ) reported only 30 offers. The figure seems surprisingly low in comparison to the number of active operators in the sector.

\section{Data}

The data set is based on the Aspects of Daily Life survey (ADL), carried out in 2014 by the Italian National Institute of Statistics (ISTAT). We observe social, demographic, geographic and economic information regarding 18,448 households and 37,217 individuals in working age or retired. In addition, the survey provides information about individual opinions, expectations, and choices regarding national utilities. For what concerns electricity and gas, it collects information on customer satisfaction, switching behavior, and electricity usage. ${ }^{17}$ The survey provides data on both households and individuals. Individual information is provided for all household components. For detailed descriptive statistics see Tables 2 and 3.

In the ADL survey, information is collected for general purposes, and therefore, with respect to works that rely on ad hoc surveys, the data do not suffer from framing effects. In addition, the survey is carried out via paper questionnaires, thereby avoiding the self-selection generated by the use of web surveys. ${ }^{18}$ The data set also includes an index of market concentration (CR3, i.e. the sum of the market shares of the three largest firms on the relevant market) computed on data from ARERA.

Our data do not include prices. This limitation afflicts many of the studies on the topic reflecting the lack of data and, possibly, the resistance of retailers in disclosing the conditions of their offers. However, as discussed in Section 2, the importance of price in electricity switching

\footnotetext{
${ }^{15}$ Hilke (2008)'s analysis of the U.S. electricity market describes similar patterns.

${ }^{16}$ Currently the official comparison tool is Portale Offerte.

${ }^{17}$ The same data have been used by Quaglione et al. (2017) in an analysis on energy-saving behavior.

${ }^{18}$ Web survey are effective, fast and cheap ways to obtain data. However, since switching crucially depends on the accessibility of information that is increasingly conveyed by the Internet, conducting a web survey is very likely to result in a biased sample. Yang (2014, p. 408) explicitly acknowledge the problem in commenting his analysis: "The sample is slightly biased toward the young, highly educated and higher incomes. These biases are likely because only respondents who had access to the Internet were recruited".
} 


\subsection{Variables and preliminary analysis}

The information of interest for our analysis is grouped in individual, household and market variables.

Individual variables characterize family members and highlight differences among households. They provide information on gender, age, education level, and use of the Internet.

Household variables include: household characteristics (number of members, age of contact person and perception of income affluence), geographic information (municipality size and region), electricity and gas related variables (electricity and gas switch together with information on the service provision). We consider the age of the contact person and the number of members to investigate different levels of consumption and economic burden. We pair this information with the size of the municipality in which the family lives and its geographic location.

The economic status of the household is captured by its satisfaction with its economic resources. This variable captures the perception of income affluence: the same level of income can be perceived as satisfactory in a relatively frugal community or as inadequate in a glamorous city. Moreover, perceived values indirectly capture individual diversity. Again, a given level of income could make one's life perceived as secure or insecure depending on his/her past history and personal attitudes.

Information about electricity includes satisfaction with the provision of information 

and the end of January 2014. Note that these switching rates refer to cumulative switches over seven years. This underestimates actual switching rates from regulated to free markets since respondents were asked if they had switched at least once in the previous seven years. Moreover, they do not account for multiple switching and they also include switches from the free to the regulated market.

Finally, the structure of the market is described by the local electricity (domestic and non-domestic) retail market concentration (W_CR3), calculated as the sum of the market shares of the first three electricity retailers in each region (NUTS 2). Concentration should reflect the number of available options for consumers.

A preliminary analysis of the distribution of these variables across the Italian regions (NUTS 2) gives some insights on the electricity market and on consumers attitudes. Electricity and gas (cumulative) switching rates are unevenly distributed across regions, with a prevalence of switching in the Northern regions (Figure 2). Overall, as reported in Table 3, the switching rate is relatively low ( $7.61 \%$ for electricity, $2.12 \%$ for gas, and $7.46 \%$ for electricity and gas) despite the high level of consumer awareness with respect to other EU countries. Consumer awareness, defined as the knowledge of opportunities, rights, and tools that empower them to participate in the retail market (e.g. to switch product or supplier, to install a self-generation facility or similar) (CEER, 2015, p. 9), in the database is about $85 \%$, whereas in Denmark consumers awareness was estimated around 50\% in 2013 (Yang, 2014) and 83\% in UK in 2010 (Iovino, 2015). In addition, the majority of respondents in the sample declare a high level of satisfaction about the information provided on service provision (about 61\%) and on bill comprehensibility (about $62 \%$ ) (Table 3 ).

The relationship between retailer choice and customer satisfaction is not very clear. Morey and Kirsch (2016) and Shin and Managi (2017) find a positive relation while, in our case, the association is strongly negative (Figure 1). The heterogeneity of behaviors and perceptions across the Italian territory shown in Figure 2 are confirmed by Figure 3. In particular, the geographic distribution of satisfaction concerning economic resources reflects the economic divide between the North and the South. Moreover, differences in switching choice are parallel to those in the

Table 4: Here 
satisfaction about provided information (Figure 3b) and in the use of the Internet (Figure 3c).

For what concerns the market structure, the data reveal a heterogeneous mapping of the market concentration (Figure 4).

Figure 1: Here

Figure 2: Here

Figure 3: Here

Figure 4: Here

\section{Results}

According to the approach illustrated in Section 4, we estimate the model described in eq. (1).

Table 5 reports the estimates of switching determinants at the household level (HH), applying the proposed parametric Bayesian MLM.

Similarly to Rowlands et al. (2004), we find that the age negatively affects switching, whereas gender is irrelevant (as in He and Reiner, 2015). Differently from findings in the surveyed literature (Ek and Söderholm, 2008; He and Reiner, 2015; McDaniel and Groothuis, 2012; Rowlands et al., 2004), the level of education has no effect on switching. An increase in the number of household members, a proxy for the amount of energy consumption and bills, increments the switching probability. The estimated value can be interpreted as an attempt to save on electricity bills.

Local differences are included via geographic indicators (NUTS1) and via the introduction of local covariates, such as municipality size and regional retail market concentration (W_CR3 calculated at the NUTS2 level). Living in municipalities with more than 10,000 inhabitants has a negative effect on switching. This contradicts the findings of Shin and Managi (2017), who find more participation in large cities and attribute the result to the presence of a higher number of retailers and to better customer support services. A previous evidence (Waddams Price et al., 2013) suggests that the value of an individual's time may differ in communities of different dimensions. Typically, metropolitan areas are busier and people tend to attach a higher value to time and hence engage less in search activities that have limited returns. Moreover, 
social networks might be tighter in smaller community, thus making the flow of information and contagion effects more likely.

The household geographic location results in differentiated switching rates as assumed in our Hypothesis II. With respect to North-Western Italy, being located in Southern Italy has a negative effect on the switching probability, whereas being located in the Islands has a positive effect mainly driven by Sardinia.

Satisfaction with the economic resources of the household reduces the probability of switching. This suggests both that incentives to save are less stringent for wealthier households and that they tend to attach a higher value to their time so that the search for better options becomes more costly (Waddams Price et al., 2013).

The level of satisfaction with the information on the electricity service has a negative effect on switching probability, showing that a more transparent contract increases the loyalty of consumers for their current retailer. More frequent access to the Internet corresponds to a higher probability of switching. The frequency of use of the Internet reflects access to a general source of information (i.e. not limited to contract and service) and the attitude - i.e. frequency - towards information seeking. Accessing the Internet not only provides information on the service but also enriches consumer awareness about forthcoming reforms in the sector, political or environmental issues. At the same time, accessing the Internet increases the exposure to advertisements inserted in contexts that are not related to the search of information on electricity provision.

The estimates confirm that switching is affected by the structure of the market (Hypothesis I). The electricity switching rate is strongly related to the gas switching rate. The estimated coefficient captures a twofold phenomenon. First, on the supply side, it shows that horizontally integrated firms experience an advantage in that they can propose joint switching and exploit the spillovers of joint marketing campaigns. Secondly, on the demand side, it shows that, if sequential switching is taken into account, once the consumer has switched retailer in one market, he/she may apply the same decision process to other services due to a learning effect and/or because the perceived switching costs are lower. Moreover, as assumed in the research hypotheses, the local market concentration has a negative impact on the switching probability (Hypothesis I). 
Table 7: Here

In order to further investigate the presence of local effects on the switching probability, we also apply a Bayesian MLM for each of the three main Italian macro-regions. ${ }^{19}$ Table 6 shows that in different institutional frameworks households and individuals behave differently, i.e. the determinants of switching and the intensity of their effect vary in space (Hypothesis II).

Gender remains unimportant for Northern Italy and Southern Italy while females are slightly more likely to switch than men in Central Italy, and possessing a graduate degree has a relevant negative effect only in the North. This information is quite interesting and would require further investigation. It could imply that having higher education leads to a better understanding of the functioning of the market and, therefore, a negative impact would witness for a sort of disillusion about real potential gains from switching. In Northern and Central Italy, economic resources do not impact on the switching decision whereas the variable is important in the Southern part of the country and impacts negatively on switching. The level of satisfaction with the provided information is associated with higher inertia in Northern and Central Italy, while it is unimportant in the South. The size of the municipality is relevant only in the South. Finally, the number of family members is more relevant in Central and Southern Italy.

To test the hypothesis that the definition of the household matters to the analysis of switching determinants and that the household is more accurately described as the bundle of the features of its members (Hypothesis III), in Table 7 we report the estimation conducted with the traditional Logit methodology at the household level (HCP).

In these models, we find no effect of the municipality size and of the market concentration rate. We therefore conclude that, in addition to the ability of incorporating individual variables in the analysis, the $\mathrm{HH}$ definition also enriches the identification of determinants.

On the methodological side, the Bayesian approach produces more accurate estimates than the classical one (see Nava et al., 2016). However, due to the quasi-complete separation problem and to the introduction of the extra variability associated with household heterogeneity, it is not possible to directly compare confidence and credibility intervals of the point estimates,

\footnotetext{
${ }^{19}$ We only report the model with higher performance identified given models' DIC.
} 
respectively shown in Table 7 and $5 .{ }^{20}$ We, therefore, indirectly compare them via forest plots in Figure 5, where a set of household variables is represented. The Bayesian estimates are consistent with the classic ones and the Bayesian method results in tighter credibility intervals, hence in a higher estimate accuracy. ${ }^{21}$

\section{Discussion and concluding remarks}

Results shed light on the switching decision in general and in the Italian retail electricity market. We have shown that the structure of the market affects the decision of switching (Hypothesis I). Market concentration reduces the scope for competition and acts negatively on the benefits the household can obtain from switching.

In Italy, there has been a steady growth of the number of operators since 2007 . The increase in potential competition, however, is harmed by the presence of big players such as the previous monopolist Enel, by a high national market concentration, and by the presence of the temporary regulated service that attracts the majority of consumers. Policies that operate on the supply side of the market should promote competition and eliminate the coexistence of the regulated and the free market. The hybrid solution was initially thought as a temporary regime to obtain a smooth transition to the free market. However, it has been repeatedly extended and is now in place until July 2020.

In addition, results show that households which have switched retailer either in the gas or in the electricity market are more likely to switch also in the other market. Therefore, policies that attract the interest on switching in one market are likely to produce positive effects on the switching rate in the other. From the viewpoint of contracts, offering the joint switching of gas and electricity would result in higher switching. It is worth noting that this would generate a competitive advantage for horizontally integrated retailers. The role of joint switching is relevant also for the Italian gas retail market which is characterized by a lower switching rate

\footnotetext{
${ }^{20}$ The classic approach assumes that there are fixed and unique model parameter values and, to make inferences on them, experiments are conducted so that a confidence interval is constructed to express knowledge uncertainty after the experiment. The Bayesian approach assumes fixed effects endowed with a suitable prior. It follows that credibility intervals have fixed bounds and random estimated parameters. Confidence intervals treat the estimated value as fixed and the bounds as random variables, without incorporating prior knowledge. Forest plots (or Blobbograms), which are frequently used in meta-analysis, are used here to compare method and model accuracy (see, among the others, Nava et al., 2016).

${ }^{21}$ The constant and the gas switch estimates are omitted for plot scale reasons, but the statistical evidence is the same of the other plotted variables.
} 
than the electricity market (in our data $9.5 \%$ over seven years vs. $15 \%$ of the electricity market) in spite of higher associated savings and of higher expenditure. ${ }^{22}$

An additional interesting feature of the Italian market is that the switching choice takes place in a heterogeneous cultural, geographic and economic context. Our estimates show that switching determinants differ across macro-regions (Hypothesis II). In Italy, households that live in the South switch less than those living in the North-West. Moreover, economic resources play a (negative) role in the switching decision only in Southern Italy, age is only important in Northern Italy whereas gender matters only in the Centre. As for education, having a highschool degree increases switching activities in Southern Italy and whereas in the North having a degree decreases the switching probability. The main implication of these findings is that even if countries have similar stated policy goals, i.e. achieving an efficient liberalized electricity market (also) through high switching rates, the instruments deployed to achieve these goals should be sufficiently differentiated to reflect the countries' distinct situation and their within country heterogeneity. There is no "one-size-fits-all" policy instrument (Monarca et al., 2015) and further effort should be dedicated to the selection of an optimal scale of analysis. For instance, the access to the Internet has a positive effect in all the macro-regions but its level varies in the Italian territory (Figure 3c). While policy imposes the presence of an official website to compare offers, our results suggest that granting more access to the Internet would promote switching activities. Accessing the Internet allows to broaden the search for information and to increase awareness of consumers about the trends of the relevant market and the available contracts and offers.

A further source of heterogeneity in the analysis of switching determinants resides in the composition of the households. We explore its implication by defining the household as the bundle of the features of its members (HH). This specification of household proves useful in identifying determinants that could not be included in the traditional approach (for instance the use of the Internet as an individual variable) and in enriching the analysis of switching behavior. Namely, the effect of economic resources was unimportant when adopting the HCP definition (Hypothesis III). Moreover, the effects of the concentration of the market and of the size of the municipality of residence on switching probability are found only when family heterogeneity is accounted for.

\footnotetext{
${ }^{22}$ The maximum saving associated with fixed-price offers, calculated on spring data, was about $€ 130$ before tax per year in 2013. For gas provision, the maximum saving, under the same conditions, was about $€ 260$ (AEEGSI, 2015, pp. 47-92). Maximum yearly expenditure is $€ 593.3$ and $€ 1581.4$ for electricity and gas respectively.
} 
The results obtained for the Italian market support our research hypotheses and suggest that the aspects included in our analysis and our methodology can improve the analysis of switching behavior in other markets.

A thorough understanding of the switching decision has implications that go beyond the knowledge of the process itself since the European Union relies on switching rates, among the other indexes (e.g. barriers to entry, innovation, price dispersion), to assess the success of the liberalization of markets. Given the uncertainty on the actual benefits the liberalization has brought to households (Concettini and Créti, 2013; Dyner and Larsen, 2001; Fehr and Hansen, 2010; Özbuğday et al., 2016; Vihalemm and Keller, 2016) the identification of the appropriate level and unit of analysis of switching behavior is also relevant to liberalization-oriented policies in general. 


\section{References}

AEEGSI, 2014. Annual report to the international agency for the cooperation of national energy regulators and to the European Commission on the regulatory activities and the fulfillment of duties of the Italian regulatory authority for electricity, gas and water. 406/2014/I.

AEEGSI, 2015. Monitoraggio retail. Rapporto annuale 2012 e 2013. 42/2015/I/COM.

Convergence failures in logistic regression (2008). Vol. 360, pp. 1-11.

Altman, M., Gill, J., McDonald, M. P., 2003. Numerical Issues in Statistical Computing for the Social Scientist. John Wiley \& Sons, New York.

Amemiya, T., 1985. Advanced Econometrics. Harvard University Press, Cambridge, MA.

Annala, S., Viljainen, S., Tuunanen, J., 2013. Rationality of supplier switching in retail electricity markets. Int. J. Energy Sect. Manag. 7, 459-477. https://doi.org/10.1108/IJESM05-2012-0002.

ARERA, 2017. Monitoraggio retail. Rapporto per l'anno 2016. 801/2017/I/COM.

Balcombe, K., Chalak, A., Fraser, I., 2009. Model selection for the mixed logit with Bayesian estimation. J. Environ. Econ. Manag. 57, 226-237.

Bolduc, D., Ben-Akiva, M., 1996. Multinomial Probit with a Logit kernel and a general parametric specification of the covariance structure. MIT working paper.

Boyd, J. H., Mellman, R. E., 1980. The effect of fuel economy standards on the US automotive market: An hedonic demand analysis. Transp. Res. Part A: General 14, 367-378. https: //doi.org/10.1016/0191-2607(80)90055-2.

Brownstone, D., Train, K., 1998. Forecasting new product penetration with flexible substitution patterns. J. Econometrics 89, 109-129. https://doi.org/10.1016/S0304-4076(98)00057-8.

Cardell, N. S., Dunbar, F. C., 1980. Measuring the societal impacts of automobile downsizing. Transp. Res. Part A: General 14, 423-434. https://doi.org/10.1016/0191-2607(80)90060-6.

Casella, G., George, E. I., 1992. Explaining the Gibbs sampler. Am. Stat. 46, 167-174. https: //doi.org/10.1080/00031305.1992.10475878.

CEER, 2015. Positional paper on well-functioning retail energy markets.

CEER, 2017. Retail markets monitoring reports.

Choi, J. Y., Shin, J., Lee, J., 2013. Strategic demand forecasts for the tablet PC market using the Bayesian mixed logit model and market share simulations. Behav. \& Inform. Tech. 32, $1177-1190$. 
Concettini, S., Créti, A., 2013. Liberalization of electricity retailing in Europe: Coming back or going forth? Cahier de recherche 2013-29.

Cox, D. R., 1989. The Analysis of Binary Data. Chapman \& Hall, London.

Daglish, T., 2016. Consumer governance in electricity markets. Energy Econ. 56, 326-337. https: //doi.org/10.1016/j.eneco.2016.03.018.

Defeuilley, C., 2009. Retail competition in electricity markets. Energy Policy 37, 377-386. https: //doi.org/10.1016/j.enpol.2008.07.025.

Dyner, I., Larsen, E. R., 2001. From planning to strategy in the electricity industry. Energy Policy 29, 1145-1154. https://doi.org/10.1016/S0301-4215(01)00040-4.

Ek, K., Söderholm, P., 2008. Households' switching behavior between electricity suppliers in Sweden. Utilities Policy 16, 254-261. https://doi.org/10.1016/j.jup.2008.04.005.

Fehr, N.-H. M. von der, Hansen, P. V., 2010. Electricity retailing in Norway. Energy J. 25-45. https://doi.org/10.5547/ISSN0195-6574-EJ-Vol31-No1-2.

Finch, W. H., Bolin, J. E., Kelley, K., 2014. Multilevel Modeling Using R. Chapman \& Hall, Boca Raton, FL.

Flores, M., Waddams Price, C., 2018. Attitudes and marketing in consumer behaviours in the British retail electricity market. Energy J. 39, 153-177. https://doi.org/10.5547/01956574. 39.4.mflo.

Fontana, M., Iori, M., Nava, C. R., 2018. Barriers to switching in retail electricity markets: A regional analysis of the Italian market, in: Bisello, A., Vettorato, D., Laconte, P., Costa, S. (Eds.), Smart and Sustainable Planning for Cities and Regions. Springer, Rotterdam, pp. 477-487. https://doi.org/10.1007/978-3-319-75774-2_32.

Gamble, A., Juliusson, E. A., Gärling, T., 2009. Consumer attitudes towards switching supplier in three deregulated markets. J. Socio-Econ. 38, 814-819. https://doi.org/10.1016/j.socec. 2009.05.002.

Gärling, T., Gamble, A., Juliusson, E. A., 2008. Consumers' switching inertia in a fictitious electricity market. Int. J. Consumer Stud. 32, 613-618. https://doi.org/10.1111/j.14706431.2008.00728.x.

Gelman, A., Carlin, J. B., Stern, H. S., Rubin, D. B., 2014. Bayesian Data Analysis. Chapman \& Hall, Boca Raton, FL.

Toward retail competition in the Portuguese electricity market (2016). IEEE, pp. 1-5. DOI: https://doi.org/10.1109/EEM.2016.7521209. 
Giulietti, M., Waddams Price, C., Waterson, M., 2005. Consumer choice and competition policy: A study of UK energy markets. Econ. J. 115, 949-968. https://doi.org/10.1111/j.14680297.2005.01026.x.

Giulietti, M., Waterson, M., Wildenbeest, M. R., 2014. Estimation of search frictions in the British electricity market. J. Ind. Econ. 4, 555-590. https://doi.org/10.1111/joie.12062.

Goldstein, H., 2011. Multilevel Statistical Models. John Wiley \& Sons, Chichester, UK.

Hadfield, J. D., 2010. MCMC Methods for multi-response generalized linear mixed models. The MCMCglmm R package. J. Stat. Softw. 33, 1-22. https://doi.org/10.18637/jss.v033.i02.

He, X., Reiner, D., 2015. Why do more British consumers not switch energy suppliers? The role of individual attitudes. Camb. work. pap. Econ. 1525.

Hensher, D. A., Greene, W. H., 2003. The mixed logit model: the state of practice. Transportation $30,133-176$.

Hilke, J. C., 2008. Economics, competition, and costs in the restructuring of US electricity markets. Rev. Ind. Organ. 32, 289-296. https://doi.org/10.1007/s11151-008-9175-y.

Hortaçsu, A., Madanizadeh, S. A., Puller, S. L., 2015. Power to choose? An analysis of consumer inertia in the residential electricity market. NBER work. pap. 20988. https://doi.org/10. $3386 / \mathrm{w} 20988$.

Iovino, F., 2015. Relationship marketing by energy companies. Rev. Manag. Comparat Int. 16, 558.

Joskow, P. L., 2000. Deregulating and regulatory reform in the US electric power sector, in: Peltzman, S., Winston, C. (Eds.), Deregulation of Network Industries: What's Next? Brookings Institution Press, Washington, DC, pp. 113-54.

Joskow, P. L., 2008. Lessons learned from electricity market liberalization. Energy J. 29, 9-43. https://doi.org/10.5547/ISSN0195-6574-EJ-Vol29-NoSI2-3.

Keaveney, S. M., 1995. Customer switching behavior in service industries: An exploratory study. J. Marketing 59, 71-82. https://doi.org/10.2307/1252074.

Klemperer, P., 1995. Competition when consumers have switching costs: An overview with applications to industrial organization, macroeconomics, and international trade. Rev. Econ. Stud. 62, 515-539. https://doi.org/10.2307/2298075.

Lesaffre, E., Albert, A., 1989. Partial separation in logistic discrimination. J. Royal Stat. Soc.: Series B 51, 109-116. https://doi.org/10.1111/j.2517-6161.1989.tb01752.x. 
Loi, T. S. A., Le Ng, J., 2018. Analysing households' responsiveness towards socio-economic determinants of residential electricity consumption in Singapore. Energy Policy 112, 415426. https://doi.org/10.1016/j.enpol.2017.09.052.

Luce, R. D., Suppes, P., 1965. Preference, utility and subjective probability, in: Luce, R. D., Bush, R. R., Galanter, E. (Eds.), Handbook of Mathematical Psychology. John Wiley \& Sons, New York, pp. 249-410.

Bayesian multinomial logistic regression for author identification (2005). Vol. 803. 1. AIP, pp. 509-516.

McCulloch, R. E., Rossi, P. E., 2000. Bayesian analysis of the multinomial Probit model, in: Mariano, R., Schuermann, T., Weeks, M. J. (Eds.), Simulation-based Inference in Econometrics: Methods and Applications. Cambridge University Press, Cambridge, pp. 158-176. https://doi.org/10.1017/CBO9780511751981.009.

McDaniel, T. M., Groothuis, P. A., 2012. Retail competition in electricity supply - Survey results in North Carolina. Energy policy 48, 315-321. https://doi.org/10.1016/j.enpol.2012.05.028.

McFadden, D., 1974. Conditional Logit analysis of qualitative choice behavior, in: Zarembka, P. (Eds.), Frontiers in Econometrics. Academic Press, New York, pp. 105-142.

McFadden, D., Train, K., 2000. Mixed MNL models for discrete response. J. App. Econometrics 15, 5447-5470. https://doi.org/10.1002/1099-1255(200009/10)15:5〈447::AID-JAE570〉3.0. $\mathrm{CO} ; 2-1$.

Monarca, U., Cassetta, E., Sarra, A., Pozzi, C., 2015. Integrating renewable energy sources into electricity markets: Power system operation, resource adequacy and market design. Econ. Policy Energy Environ. 2015, 149-166. https://doi.org/10.3280/EFE2015-002010.

Morey, M. J., Kirsch, L. D., 2016. Retail choice in electricity: What have we learned in 20 years. Christensen Associates Energy Consulting LLC for Electric Markets Research Foundation, Washington, DC.

Nava, C. R., Carota, C., Colombino, U. (2016). Bayesian methods for microsimulation models. Ed. by R. Argiento, E. Lanzarone, I. Antoniano Villalobos, A. Mattei. Dor: https://doi.org/ 10.1007/978-3-319-54084-9_18.

Özbuğday, F. C., Öğünlü, B., Alma, H., 2016. The sustainability of Turkish electricity distributors and last-resort electricity suppliers: What did transition from vertically integrated public monopoly to regulated competition with privatized and unbundled firms bring about? Utilities Policy 39, 50-67. https://doi.org/10.1016/j.jup.2015.10.003. 
Peng, L. Y., Wang, Q., 2006. Impact of relationship marketing tactics (RMTs) on switchers and stayers in a competitive service industry. J. Marketing Manag. 22, 25-59. https://doi.org/ 10.1362/026725706776022263.

Quaglione, D., Cassetta, E., Crociata, A., Sarra, A., 2017. Exploring additional determinants of energy-saving behaviour: The influence of individuals' participation in cultural activities. Energy Policy 108, 503-511. https://doi.org/10.1016/j.enpol.2017.06.030.

Rigby, D., Burton, M., 2006. Modeling disinterest and dislike: A bounded Bayesian mixed logit model of the UK market for GM food. Environ. Resour Econ. 33, 485-509.

Rowlands, I. H., Parker, P., Scott, D., 2004. Consumer behaviour in restructured electricity markets. J. Consumer Behav. 3, 272-283. https://doi.org/10.1002/cb.140.

Sauthoff, S., Danne, M., Mußhoff, O., 2017. To switch or not to switch? Understanding German consumers' willingness to pay for green electricity tariff attributes. Diskussionspapiere, Department für Agrarökonomie und Rurale Entwicklung.

Schleich, J., Faure, C., Gassmann, X., 2017. Household electricity contract and provider switching in the EU. Working Paper Sustainability and Innovation 14/2017.

Shin, K. J., Managi, S., 2017. Liberalization of a retail electricity market: Consumer satisfaction and household switching behavior in Japan. Energy Policy 110, 675-685. https://doi.org/ 10.1016/j.enpol.2017.07.048.

Sirin, S. M., Gonul, M. S., 2016. Behavioral aspects of regulation: A discussion on switching and demand response in Turkish electricity market. Energy Policy 97, 591-602. https://doi. org/10.1016/j.enpol.2016.08.005.

Steiner, F., 2004. The market response to restructuring: A behavioral model. J. Regul. Econ. 25, 59-80. https://doi.org/10.1023/B:REGE.0000008655.66589.0e.

Szymanski, D. M., Henard, D. H., 2001. Customer satisfaction: A meta-analysis of the empirical evidence. J. Acad. Marketing Sci. 29, 16-35. https://doi.org/10.1177/0092070301291002.

Train, K., 2001. A comparison of hierarchical Bayes and maximum simulated likelihood for mixed logit. University of California, Berkeley, 1-13.

Train, K., 2003. Discrete Choice Methods with Simulation. Cambridge University Press, Cambridge.

Vesterberg, M., 2018. The effect of price on electricity contract choice. Energy Econ. 69, 59-70. https://doi.org/10.1016/j.eneco.2017.10.039. 
Vihalemm, T., Keller, M., 2016. Consumers, citizens or citizen-consumers? Domestic users in the process of Estonian electricity market liberalization. Energy Res. \& Soc. Sci. 13, 38-48. https://doi.org/10.1016/j.erss.2015.12.004.

Waddams Price, C., Webster, C., Zhu, M., 2013. Searching and switching: Empirical estimates of consumer behaviour in regulated markets. Centre Competition Policy work. pap. 13/11.

Webb, M. C., Wilson, J. R., Chong, J., 2004. An analysis of quasi-complete binary data with logistic models: Applications to alcohol abuse data. J. Data Sci. 2, 273-285.

Wieringa, J. E., Verhoef, P. C., 2007. Understanding customer switching behavior in a liberalizing service market: An exploratory study. J. Serv. Res. 10, 174-186. https://doi.org/10. $1177 / 1094670507306686$.

Wilson, C. M., Waddams Price, C., 2010. Do consumers switch to the best supplier? Oxf. Econ. Pap. 62, 647-668. https://doi.org/10.1093/oep/gpq006.

Wirtz, J., Xiao, P., Chiang, J., Malhotra, N., 2014. Contrasting the drivers of switching intent and switching behavior in contractual service settings. J. Retail. 90, 463-480. https://doi. $\operatorname{org} / 10.1016 / j . j r e t a i .2014 .07 .002$.

Yang, Y., 2014. Understanding household switching behavior in the retail electricity market. Energy Policy 69, 406-414. https://doi.org/10.1016/j.enpol.2014.03.009.

Zorn, C., 2005. A solution to separation in binary response models. Political Anal. 13, 157-170. https://doi.org/10.1093/pan/mpi009. 


\title{
Appendix
}

\section{A Methodological approaches in literature}

\author{
Table 8: Here
}

\section{B Logit and Mixed Logit models}

The (discrete) switching choice is driven by a utility maximization process (random utility model). We represent the decision of household $i(\forall i=1, \ldots, n)$ as the choice of $j$ among a choice set composed of the two alternatives: $j \in\{S, N S\}$, i.e. switch $(j=S)$ and non-switch $(j=N S)$. Hence, the switching response of the $i^{\text {th }}$ household, i.e. $Y_{i}$, is a binary random variable equal to 1 if the household switches and equal to 0 if it does not switch.

By selecting the alternative $Y_{i}=j$, the decision maker $i$ will obtain a utility, $U_{i j}$, modeled as a random variable with a systematic (observed), $V_{i j}$, and a stochastic (unobserved), $\varepsilon_{i j}$, component, i.e. $U_{i j}=V_{i j}+\varepsilon_{i j}$. Therefore, the household $i$ will select the alternative $Y_{i}=1$ if and only if $U_{i 1}>U_{i 0}$, where $U_{i 0}$ is the utility associated with the non switch option. We assume standard Gumbel independent and identically distributed (i.i.d.) errors, derived as a particular parametrisation of the generalized extreme value distribution. This assumption allows to derive a Logit model starting from the Random Utility theory (see, among the others, Train, 2003). Given the heavy tails of the Gumbel distribution, we obtain a better model household choices. Its use is close to assuming independent normal errors, except that the heavy tails allow more robust analyses taking into account a "slightly more aberrant behavior than the normal" (Train, 2003, p. 39). The systematic component of the utility is assumed to be linear in model parameters, i.e. $V_{i j}=\mathbf{x}_{i j}^{\prime} \boldsymbol{\beta}$. Hence, the switching probability reduces to

$$
\pi_{i}=\mathrm{P}\left(Y_{i}=1 \mid X_{i}=\mathbf{x}_{i 1}\right)=\frac{e^{\mathbf{x}_{i 1}^{\prime} \boldsymbol{\beta}}}{1+e^{\mathbf{x}_{i 1}^{\prime} \boldsymbol{\beta}}}
$$

where $\mathbf{x}_{i 1}$ represents the $p \times 1$ vector of observed explanatory variables (for individual $i$ and choice $j=1$ ) and $\boldsymbol{\beta}$ is a $p \times 1$ vector of fixed effects (here with $p-1$ covariates and an intercept). For the ease of exposition, we do not report the $j \in\{0,1\}$ alternative indicator in the rest of the discussion.

Let us introduce a random effect based on a grouping variable, e.g. the household id, 
to correctly account for the household member characteristics. Formally, this results in the following specification. Let $Y_{k r}$ be the common response variable of individual $r$ in the household $k$ for $r=1, \ldots, R_{k}$ with $R_{k}$ the number of members of household $k, k=1, \ldots, K$. Moreover, $\mathbf{x}_{k r}$ represents the vector of the values of individual level explanatory variables, for fixed effect model parameters $\boldsymbol{\beta}$. In our case, we assume only a random intercept, i.e a univariate random effect $u_{k}$, following Goldstein (2011) and Nava et al. (2016) to suitably model the common individual choice in the household and its heterogeneity. Therefore, the error components $u_{k}$ is common to all $R_{k}$ household members, i.e. $V_{k r}=\mathbf{x}_{k r}^{\prime} \boldsymbol{\beta}+u_{k}$. Thus

$$
\pi_{k r}=\frac{e^{\mathbf{x}_{k r}^{\prime} \boldsymbol{\beta}+u_{k}}}{1+e^{\mathbf{x}_{k r}^{\prime} \boldsymbol{\beta}+u_{k}}}
$$

\section{The parametric Bayesian MLM}

Bayesian methods allows to specify prior information via the selection of a prior distribution $\pi(\boldsymbol{\theta})$ for the unknown model parameters $\boldsymbol{\theta}$. After data observation, based on the likelihood function $L(\mathbf{Y} \mid \boldsymbol{\theta})$, the updated prior knowledge results in a posterior distribution $\pi(\boldsymbol{\theta} \mid \mathbf{Y}) \propto L(\mathbf{Y} \mid \boldsymbol{\theta}) \pi(\boldsymbol{\theta})$, on which the Bayesian estimations $\hat{\boldsymbol{\theta}}$ are determined, i.e.

$$
\hat{\boldsymbol{\theta}}=\int \boldsymbol{\theta} \pi(\boldsymbol{\theta} \mid \boldsymbol{Y}) d \boldsymbol{\theta}
$$

The parametric Bayesian MLM, with model parameters $\boldsymbol{\theta}=(\boldsymbol{\beta}, \boldsymbol{u})$ (Goldstein, 2011), is a particular case of the more general Bayesian multinomial mixed Logit model proposed in Nava et al. (2016). Normal prior distributions are assumed for fixed $(\boldsymbol{\beta})$ and random $(\boldsymbol{u})$ effect model parameters with mean and (co)variance, respectively, $\left(\mu_{\boldsymbol{\beta}}, \Sigma_{\beta}^{2}\right)$ and $\left(\mu_{\boldsymbol{u}}, \Sigma_{\boldsymbol{u}}^{2}\right)$. We assign an IW prior distribution to $\Sigma_{\boldsymbol{u}}^{2}$. Therefore, the posterior for $\boldsymbol{\beta}, \boldsymbol{u}$ and $\Sigma_{\boldsymbol{u}}^{2}$ is

$$
\pi\left(\boldsymbol{\beta}, \boldsymbol{u}, \Sigma_{\boldsymbol{u}}^{2} \mid \boldsymbol{Y}\right) \propto \prod_{k=1}^{K} \prod_{r=1}^{R_{k}} L\left(Y_{k r} \mid \boldsymbol{\beta}, u_{k}\right) \pi(\boldsymbol{\beta}) \pi\left(u_{k} \mid \mu_{\boldsymbol{u}}, \Sigma_{\boldsymbol{u}}^{2}\right) \pi\left(\Sigma_{\boldsymbol{u}}^{2}\right)
$$

The conditional posteriors for the block Gibbs sampling of the proposed Bayesian mixed Logit 
model, following Train (2003) and Nava et al. (2016), is

$$
\begin{aligned}
& \pi\left(\boldsymbol{u} \mid \boldsymbol{\beta}, \mu_{\boldsymbol{u}}, \Sigma_{\boldsymbol{u}}^{2}\right) \propto \prod_{k=1}^{K} \prod_{r=1}^{R_{k}} L\left(Y_{k r} \mid \boldsymbol{\beta}, u_{k}, \Sigma_{\boldsymbol{u}}^{2}\right) N\left(u_{k} \mid \mu_{\boldsymbol{u}}, \Sigma_{\boldsymbol{u}}^{2}\right) \\
& \pi\left(\Sigma_{\boldsymbol{u}}^{2} \mid \boldsymbol{u}\right) \sim \operatorname{IW}(\mathrm{M}+N,(\mathrm{MI}+N S) /(\mathrm{M}+N)) \\
& \pi(\boldsymbol{\beta} \mid \boldsymbol{u}) \propto \prod_{k=1}^{K} \prod_{r=1}^{R_{k}} L\left(Y_{k r} \mid \boldsymbol{\beta}, u_{k}\right) \pi(\boldsymbol{\beta}) .
\end{aligned}
$$

Where $\mathrm{M}$ and I are the Inverse-Wishart parameters and $S=\left(\boldsymbol{u}-\mu_{\boldsymbol{u}}\right)\left(\boldsymbol{u}-\mu_{\boldsymbol{u}}\right)^{T} / N$. 
Switching behavior in the Italian electricity retail market: Logistic and mixed effect Bayesian estimations of consumer choice.

\author{
Abstract \\ Highlights \\ - Switching determinants depend on the context of choice \\ - Bayesian econometric analysis explains switching probability at the individual \\ and household level \\ - The structure of the market affects the switching decision \\ - Switching depends on the individual characteristics of all the household mem- \\ bers
}


Switching behavior in the Italian electricity retail

Figure(s)

\section{market: Logistic and mixed effect Bayesian estimations of consumer choice.}




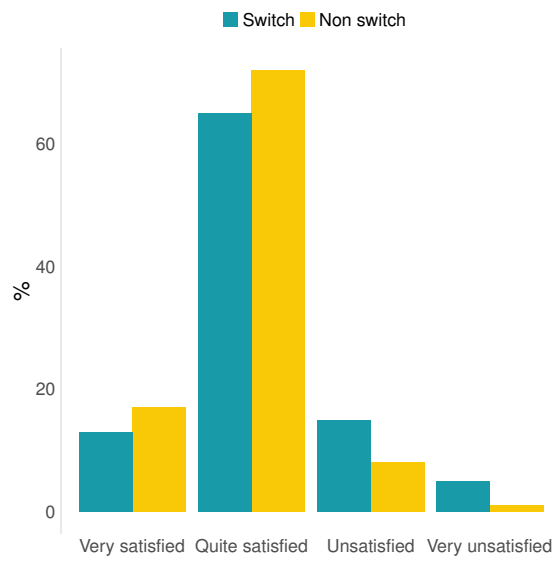

Figure 1: Satisfaction with provided electricity services. Source: our elaboration (ADL 2014)

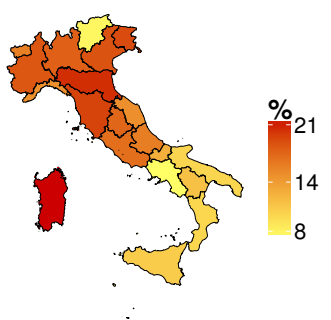

(a) Electricity switching rate $[7.16 \%-21.57 \%]$

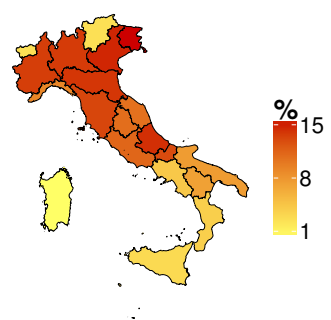

(b) Gas switching rate [0.27\% - $15.62 \%]$

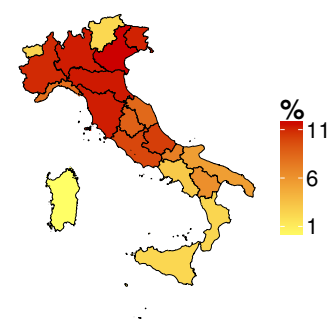

(c) Joint electricity and gas switching rate [0.13\% - 11.60\%]

Figure 2: Electricity and/or gas switching rates at the regional (NUTS2) level. Source: our elaboration (ADL 2014) 


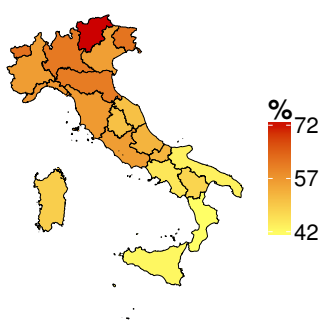
(a) Good economic resources $[41.49 \%-72.57 \%]$

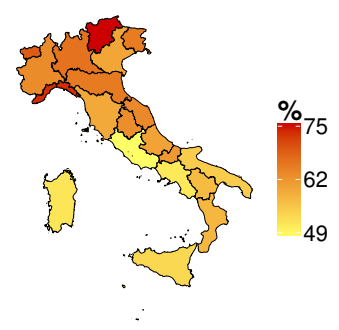

(b) Satisfaction about provided information $[48.23 \%-75.30 \%]$

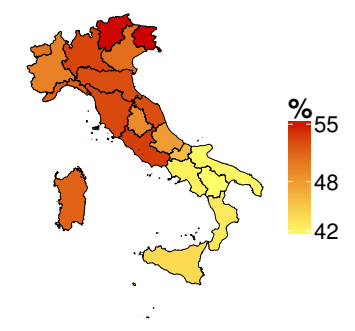

(c) Frequent use of the Internet

[41.18\% - 55.41\%]

Figure 3: Economic resources, information quality and quantity variables at the regional (NUTS2) level. Source: our elaboration (ADL 2014)

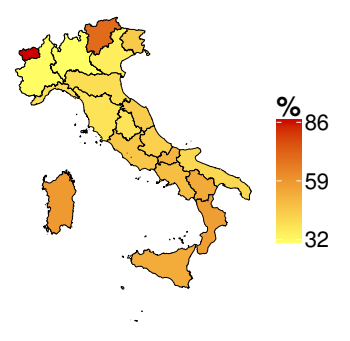

Figure 4: Retail market concentration at regional (NUTS2) level [31.4\% 86.5\%]. Source: our elaboration (ARERA) 


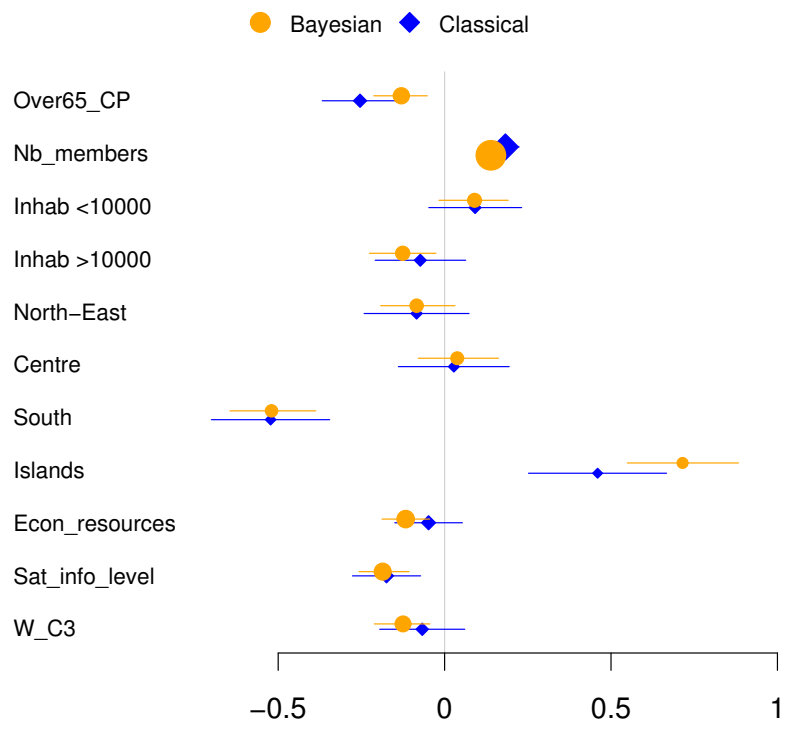

Figure 5: Comparison between Bayesian mixed Logit and Bayesian (household) Logit estimates (Tables 5 and 7). Forest plots report, respectively, credibility intervals (circle) and confidence intervals (rhombus) for selected household variables. The box size is based on estimate precision. Source: our elaboration (ADL 2014) 
Switching behavior in the Italian electricity retail market: Logistic and mixed effect Bayesian estimations of consumer choice. 
Table 1: Switching determinants in the literature

\begin{tabular}{|c|c|c|c|}
\hline Determinants & Drivers & $\begin{array}{l}\text { Effect } \\
+: \text { positive } \\
-: \text { negative } \\
\quad=: \text { neutral }\end{array}$ & Articles \\
\hline \multirow[t]{3}{*}{ Economic } & Electricity Price &,$+=$ & $\begin{array}{l}\text { Giulietti, Waterson, et al. (2014), } \\
\text { Klemperer (1995), Sirin and Gonul } \\
(2016), \text { and Wieringa and Verhoef } \\
(2007) \text {. }\end{array}$ \\
\hline & Switching costs & - & $\begin{array}{l}\text { Sirin and Gonul (2016) and Wieringa } \\
\text { and Verhoef (2007). }\end{array}$ \\
\hline & Income &,+- & $\begin{array}{l}\text { Ek and Söderholm (2008), Fontana } \\
\text { et al. (2018), Gamble et al. (2009), } \\
\text { Giulietti, Waddams Price, et al. (2005), } \\
\text { and Rowlands et al. (2004). }\end{array}$ \\
\hline \multirow[t]{3}{*}{ Demographic } & Age &,$-=$ & $\begin{array}{l}\text { Fontana et al. (2018), He and Reiner } \\
\text { (2015), and Rowlands et al. (2004). }\end{array}$ \\
\hline & Gender & $+($ Male $),=$ & Gamble et al. (2009) \\
\hline & Education & + & $\begin{array}{l}\text { Ek and Söderholm (2008), He and } \\
\text { Reiner (2015), McDaniel and Groothuis } \\
\text { (2012), and Rowlands et al. (2004). }\end{array}$ \\
\hline \multirow[t]{4}{*}{ Psychological } & Loyalty & - & $\begin{array}{l}\text { Daglish (2016), Gamble et al. (2009), } \\
\text { and Szymanski and Henard (2001). }\end{array}$ \\
\hline & Risk aversion & - & $\begin{array}{l}\text { Schleich et al. (2017) and Sirin and } \\
\text { Gonul (2016). }\end{array}$ \\
\hline & Satisfaction & - & $\begin{array}{l}\text { Keaveney (1995), Wieringa and Verhoef } \\
(2007) \text {, and Yang (2014). }\end{array}$ \\
\hline & Learning & + & $\begin{array}{l}\text { Defeuilley (2009), Fontana et al. (2018), } \\
\text { Giulietti, Waddams Price, et al. (2005), } \\
\text { McDaniel and Groothuis (2012), and } \\
\text { Wirtz et al. (2014). }\end{array}$ \\
\hline Information & Service and Contract & + & $\begin{array}{l}\text { Flores and Waddams Price (2018), } \\
\text { Fontana et al. (2018), Gärling et al. } \\
\text { (2008), He and Reiner (2015), Hortaçsu } \\
\text { et al. (2015), and Loi and Le } \mathrm{Ng}(2018) .\end{array}$ \\
\hline \multirow[t]{3}{*}{ Other } & Green energy & + & $\begin{array}{l}\text { Gärling et al. (2008), Sauthoff et al. } \\
\text { (2017), and Shin and Managi (2017). }\end{array}$ \\
\hline & Political Elections & + & He and Reiner (2015). \\
\hline & Number of Contracts & - & $\begin{array}{l}\text { Annala et al. (2013) and Wieringa and } \\
\text { Verhoef (2007) }\end{array}$ \\
\hline Market Structure & Concentration Index & & - \\
\hline Local effects & $\begin{array}{l}\text { Household place of } \\
\text { residence }\end{array}$ & & - \\
\hline
\end{tabular}


Table 2: Descriptive statistics: individual and household variables. Source: our elaboration (ADL 2014)

\begin{tabular}{|c|c|c|c|c|c|}
\hline Individual variables & $\mathbf{N}$ & $\%$ & Household variables & $\mathbf{N}$ & $\%$ \\
\hline Sex & & & \multicolumn{3}{|l|}{ Number of members } \\
\hline Male & 21115 & 48.47 & 1 & 5613 & 30.43 \\
\hline Female & 22452 & 51.53 & 2 & 5257 & 28.5 \\
\hline Age & & & 3 & 3654 & 19.81 \\
\hline Not in working age $(<16)$ & 6350 & 14.58 & 4 & 3000 & 16.26 \\
\hline In working age(16-64) & 27253 & 62.55 & $5+$ & 924 & 5.01 \\
\hline $\operatorname{Retired}(>64)$ & 9964 & 22.87 & \multicolumn{3}{|l|}{ Size of municipality } \\
\hline Education (over 16) & & & Metropolitan area & 3788 & 20.53 \\
\hline University & 4657 & 12.51 & More than 10000 inhab. & 8227 & 44.6 \\
\hline High school & 13314 & 35.78 & Less than 10000 inhab. & 6433 & 34.87 \\
\hline Secondary school & 11452 & 30.77 & \multicolumn{3}{|l|}{ Geographical area (NUTS1) } \\
\hline Primary school & 6334 & 17.02 & North-Western Italy & 4156 & 22.53 \\
\hline No education & 1460 & 3.92 & North-Eastern Italy & 4002 & 21.69 \\
\hline Employment status (over 1 & & & Central Italy & 3282 & 17.79 \\
\hline Employed & 15158 & 40.73 & Southern Italy & 5104 & 27.67 \\
\hline Job-seeker & 4448 & 11.95 & Insular Italy & 1904 & 10.32 \\
\hline Housewife & 5432 & 14.59 & \multicolumn{3}{|l|}{ Economic resources } \\
\hline Student & 2727 & 7.33 & Excellent & 161 & 0.87 \\
\hline Retired & 8358 & 22.46 & Good & 9831 & 53.29 \\
\hline Other & 1094 & 2.94 & Insufficient & 7216 & 39.12 \\
\hline \multicolumn{3}{|l|}{ Use of the Internet (over 16) } & Absolutely insufficient & 1240 & 6.72 \\
\hline Frequent & 19185 & 51.55 & & & \\
\hline Occasional & 18032 & 48.45 & & & \\
\hline
\end{tabular}

Table 3: Descriptive statistics: electricity-related variables. Source: our elaboration (ADL 2014)

\begin{tabular}{lrr}
\hline Electricity variables & $\mathbf{N}$ & $\mathbf{\%}$ \\
\hline Satisfaction with services provided & & \\
Very satisfied & 3087 & 16.75 \\
Quite satisfied & 13100 & 71.09 \\
Unsatisfied & 1798 & 9.76 \\
Very unsatisfied & 443 & 2.4 \\
Satisfaction with bill comprehensibility & & \\
Very satisfied & 2102 & 11.46 \\
Quite satisfied & 9216 & 50.22 \\
Unsatisfied & 5198 & 28.33 \\
Very unsatisfied & 1834 & 9.99 \\
Satisfaction with information provided & & \\
Very satisfied & 1838 & 10.07 \\
Quite satisfied & 9242 & 50.66 \\
Unsatisfied & 5299 & 29.05 \\
Very unsatisfied & 1865 & 10.22 \\
Knowledge of switching possibility & & \\
Yes & 15616 & 84.65 \\
No & 2832 & 15.35 \\
Supplier switch & & \\
Only electricity & 1404 & 7.61 \\
Only gas & 391 & 2.12 \\
Electricity and gas & 1376 & 7.46 \\
None & 15277 & 82.81 \\
\hline & & \\
&
\end{tabular}


Table 4: Variables description

\section{Dependent variable}

Electricity_retailer_switch Dummy variable: 1 for families that switched electricity retailer between July 2007 - end of Jan 2014

\section{Explanatory variables}

\begin{tabular}{|c|c|}
\hline \multirow{2}{*}{\multicolumn{2}{|c|}{ Individual }} \\
\hline & \\
\hline Over65 & Dummy variable: 1 for individuals with age $>65$ \\
\hline Degree & $\begin{array}{l}\text { Dummy variable: } 1 \text { for individuals with a univer- } \\
\text { sity degree as highest educational level }\end{array}$ \\
\hline Diploma & $\begin{array}{l}\text { Dummy variable: } 1 \text { for individuals with a diploma } \\
\text { as highest educational level }\end{array}$ \\
\hline Frequent_Internet_user & $\begin{array}{l}\text { Dummy variable: } 1 \text { for individuals that navigate } \\
\text { the Internet more than once a week }\end{array}$ \\
\hline \multicolumn{2}{|l|}{ Household } \\
\hline Over65_CP & $\begin{array}{l}\text { Dummy variable: } 1 \text { for contact person with age } \\
>65\end{array}$ \\
\hline Nb_members & Number of family members \\
\hline Inhab & $\begin{array}{l}\text { Categorical variable: municipality size, with lev- } \\
\text { els Metropolitan Area, < } 10000 \text { inhabitants, > } \\
10000 \text { inhabitants }\end{array}$ \\
\hline Geo & $\begin{array}{l}\text { Categorical variable: geographical distribution } \\
\text { (NUTS1), with levels North-West, North-East, } \\
\text { Centre, South, Islands }\end{array}$ \\
\hline Econ_resources & $\begin{array}{l}\text { Dummy variable: } 1 \text { for satisfactory level of eco- } \\
\text { nomic resources }\end{array}$ \\
\hline Sat_info_level & $\begin{array}{l}\text { Dummy variable: } 1 \text { for contact person that re- } \\
\text { ports having satisfactory information on electric- } \\
\text { ity service and provision }\end{array}$ \\
\hline Gas_retailer_switch & $\begin{array}{l}\text { Dummy variable: } 1 \text { for families that switched gas } \\
\text { retailer between July } 2007 \text { - end of Jan } 2014\end{array}$ \\
\hline \multicolumn{2}{|l|}{ Market } \\
\hline W_CR3 & $\begin{array}{l}\text { Dummy variable: } 1 \text { for regional market con- } \\
\text { centration (CR3) }>\text { national weighted average } \\
\text { (weights }=\text { regional populations) }\end{array}$ \\
\hline
\end{tabular}


Table 5: Bayesian mixed Logit model for the electricity retailer switch with individual and household specific covariates $(\mathrm{HH})$. Household id random intercepts. Naive standard errors in parentheses

Dependent variable:

Electricity_retailer_switch

$(1)$

$(2)$

(3)

(4)

\begin{tabular}{|c|c|c|c|c|}
\hline \multicolumn{5}{|l|}{ Individual } \\
\hline Female & $\begin{array}{c}0.0407 \\
(0.0003)\end{array}$ & $\begin{array}{c}-0.0297^{*} \\
(0.0002)\end{array}$ & $\begin{array}{c}0.0293 \\
(0.0005)\end{array}$ & $\begin{array}{c}0.0115 \\
(0.0001)\end{array}$ \\
\hline Over65 & $\begin{array}{c}0.0639^{* * *} \\
(0.0003)\end{array}$ & $\begin{array}{c}0.0721 \\
(0.0007)\end{array}$ & $\begin{array}{c}0.0782 \\
(0.0010)\end{array}$ & $\begin{array}{c}0.0200 \\
(0.0002)\end{array}$ \\
\hline Degree & $\begin{array}{l}-0.0476 \\
(0.0004)\end{array}$ & $\begin{array}{c}0.0871 \\
(0.0005)\end{array}$ & $\begin{array}{l}0.1018^{*} \\
(0.0005)\end{array}$ & $\begin{array}{c}0.0158 \\
(0.0002)\end{array}$ \\
\hline Diploma & $\begin{array}{l}-0.0182 \\
(0.0003)\end{array}$ & $\begin{array}{l}0.1024^{* *} \\
(0.0005)\end{array}$ & $\begin{array}{c}0.0510 \\
(0.0005)\end{array}$ & $\begin{array}{l}-0.0219 \\
(0.0002)\end{array}$ \\
\hline Frequent_Internet_user & $\begin{array}{c}0.2501^{* * *} \\
(0.0004)\end{array}$ & $\begin{array}{c}0.3173^{* * *} \\
(0.0004)\end{array}$ & $\begin{array}{c}0.3320^{* * *} \\
(0.0006)\end{array}$ & $\begin{array}{c}0.4251^{* * *} \\
(0.0001)\end{array}$ \\
\hline \multicolumn{5}{|l|}{ Household } \\
\hline Over65_CP & $\begin{array}{c}-0.2243^{* * *} \\
(0.0006)\end{array}$ & $\begin{array}{l}-0.0929 \\
(0.0006)\end{array}$ & $\begin{array}{c}-0.3083^{* * *} \\
(0.0008)\end{array}$ & $\begin{array}{c}-0.1299^{* * *} \\
(0.0004)\end{array}$ \\
\hline Nb_members & $\begin{array}{c}0.1831^{* * *} \\
(0.0002)\end{array}$ & $\begin{array}{c}0.1951^{* * *} \\
(0.0002)\end{array}$ & $\begin{array}{c}0.2377^{* * *} \\
(0.0003)\end{array}$ & $\begin{array}{c}0.1394^{* * *} \\
(0.0002)\end{array}$ \\
\hline Inhab $<10000$ & $\begin{array}{l}0.1065^{* *} \\
(0.0005)\end{array}$ & $\begin{array}{l}0.1086^{*} \\
(0.0006)\end{array}$ & $\begin{array}{l}0.1961^{* *} \\
(0.0008)\end{array}$ & $\begin{array}{c}0.0897 \\
(0.0005)\end{array}$ \\
\hline Inhab >10000 & $\begin{array}{c}-0.0901^{*} \\
(0.0005)\end{array}$ & $\begin{array}{l}-0.0171 \\
(0.0006)\end{array}$ & $\begin{array}{l}-0.0497 \\
(0.0008)\end{array}$ & $\begin{array}{c}-0.1256^{* *} \\
(0.0005)\end{array}$ \\
\hline North-East & $\begin{array}{c}-0.1233^{* *} \\
(0.0006)\end{array}$ & $\begin{array}{c}-0.2329^{* * *} \\
(0.0007)\end{array}$ & $\begin{array}{l}-0.1120 \\
(0.0009)\end{array}$ & $\begin{array}{l}-0.0838 \\
(0.0006)\end{array}$ \\
\hline Centre & $\begin{array}{c}0.0987 \\
(0.0008)\end{array}$ & $\begin{array}{l}-0.0621 \\
(0.0006)\end{array}$ & $\begin{array}{l}0.0998 \\
(0.010)\end{array}$ & $\begin{array}{c}0.0380 \\
(0.0006)\end{array}$ \\
\hline South & $\begin{array}{c}-0.5686^{* * *} \\
(0.0006)\end{array}$ & $\begin{array}{c}-0.7553^{* * *} \\
(0.0008)\end{array}$ & $\begin{array}{c}-0.6130^{* * *} \\
(0.0012)\end{array}$ & $\begin{array}{c}-0.5199^{* * *} \\
(0.0007)\end{array}$ \\
\hline Islands & $\begin{array}{c}0.6093^{* * *} \\
(0.0007)\end{array}$ & $\begin{array}{c}0.3543^{* * *} \\
(0.0007)\end{array}$ & $\begin{array}{c}0.8259^{* * *} \\
(0.0012)\end{array}$ & $\begin{array}{c}0.7152^{* * *} \\
(0.0009)\end{array}$ \\
\hline Econ_resources & $\begin{array}{l}-0.0111 \\
(0.0004)\end{array}$ & $\begin{array}{c}-0.1771^{* * *} \\
(0.0005)\end{array}$ & $\begin{array}{c}-0.2279^{* * *} \\
(0.0008)\end{array}$ & $\begin{array}{c}-0.1167^{* * *} \\
(0.0004)\end{array}$ \\
\hline Sat_info_level & & $\begin{array}{c}-0.1875^{* * *} \\
(0.0004)\end{array}$ & & $\begin{array}{c}-0.1862^{* * *} \\
(0.0004)\end{array}$ \\
\hline Gas_retailer_switch & $\begin{array}{c}5.5726^{* * *} \\
(0.0013)\end{array}$ & $\begin{array}{c}5.7719^{* * *} \\
(0.0015)\end{array}$ & $\begin{array}{c}7.0464^{* * *} \\
(0.0005)\end{array}$ & $\begin{array}{c}5.5026^{* * *} \\
(0.0007)\end{array}$ \\
\hline \multicolumn{5}{|l|}{ Market } \\
\hline W_CR3 & & & $\begin{array}{c}-0.1592^{* *} \\
(0.0007)\end{array}$ & $\begin{array}{c}-0.1246^{* * *} \\
(0.0004)\end{array}$ \\
\hline Constant & $\begin{array}{c}-3.9992^{* * *} \\
(0.0009)\end{array}$ & $\begin{array}{c}-3.9459^{* * *} \\
(0.0011)\end{array}$ & $\begin{array}{c}-4.9494^{* * *} \\
(0.0003)\end{array}$ & $\begin{array}{c}-3.7150^{* * *} \\
(0.0001)\end{array}$ \\
\hline Observations & 37,217 & 36,814 & 37,217 & 36,814 \\
\hline Deviance Inf. Crit. & $11,708.950$ & $11,590.080$ & $10,576.810$ & $10,565.40$ \\
\hline
\end{tabular}


Table 6: Bayesian mixed Logit estimates of individual and household specific switching determinants (HH). Analyses performed on the sub-populations of the North, Centre and South of Italy with household id random intercepts. Naive standard errors in parentheses

\begin{tabular}{|c|c|c|c|}
\hline & \multicolumn{3}{|c|}{ Dependent variable: } \\
\hline & \multicolumn{3}{|c|}{ Electricity_retailer_switch } \\
\hline & North & Centre & South \\
\hline \multicolumn{4}{|l|}{ Individual } \\
\hline Female & $\begin{array}{c}0.0104 \\
(0.0002)\end{array}$ & $\begin{array}{c}0.0135^{*} \\
(0.0070)\end{array}$ & $\begin{array}{c}0.1305 \\
(0.0006)\end{array}$ \\
\hline Over65 & $\begin{array}{c}0.2652^{* * *} \\
(0.0010)\end{array}$ & $\begin{array}{c}0.3240 \\
(0.0017)\end{array}$ & $\begin{array}{c}0.1989 \\
(0.0008)\end{array}$ \\
\hline Degree & $\begin{array}{c}-0.1084^{* * *} \\
(0.0004)\end{array}$ & $\begin{array}{c}0.2168 \\
(0.0018)\end{array}$ & $\begin{array}{c}0.3971 \\
(0.0013)\end{array}$ \\
\hline Diploma & $\begin{array}{c}0.0497 \\
(0.0006)\end{array}$ & $\begin{array}{c}0.3257 \\
(0.0015)\end{array}$ & $\begin{array}{l}0.0108^{*} \\
(0.0005)\end{array}$ \\
\hline Frequent_Internet_user & $\begin{array}{c}0.5054^{* * *} \\
(0.0006)\end{array}$ & $\begin{array}{c}0.5708^{* * *} \\
(0.0014)\end{array}$ & $\begin{array}{c}0.5099^{* * *} \\
(0.0006)\end{array}$ \\
\hline \multicolumn{4}{|l|}{ Household } \\
\hline Over65_CP & $\begin{array}{c}-0.1829^{* * *} \\
(0.0012)\end{array}$ & $\begin{array}{c}0.6293 \\
(0.0025)\end{array}$ & $\begin{array}{c}-0.1029^{* *} \\
(0.0018)\end{array}$ \\
\hline Nb_members & $\begin{array}{c}0.2639^{* * *} \\
(0.0003)\end{array}$ & $\begin{array}{c}0.3682^{* * *} \\
(0.0008)\end{array}$ & $\begin{array}{c}0.3709^{* *} \\
(0.0007)\end{array}$ \\
\hline Inhab $<10000$ & $\begin{array}{l}0.0084^{*} \\
(0.0014)\end{array}$ & $\begin{array}{c}0.2944 \\
(0.0022)\end{array}$ & $\begin{array}{c}0.5563 \\
(0.0021)\end{array}$ \\
\hline Inhab $>10000$ & $\begin{array}{c}-0.1808^{* * *} \\
(0.0012)\end{array}$ & $\begin{array}{c}0.4192 \\
(0.0023)\end{array}$ & $\begin{array}{c}-0.0132^{* *} \\
(0.0023)\end{array}$ \\
\hline Econ_resources & $\begin{array}{c}0.0331 \\
(0.0006)\end{array}$ & $\begin{array}{c}0.417 \\
(0.023)\end{array}$ & $\begin{array}{c}-0.0271^{* *} \\
(0.0010)\end{array}$ \\
\hline Sat_info_level & $\begin{array}{c}-0.3380^{* * *} \\
(0.0007)\end{array}$ & $\begin{array}{c}-0.2383^{* * *} \\
(0.0015)\end{array}$ & $\begin{array}{c}0.1104 \\
(0.0014)\end{array}$ \\
\hline Gas_retailer_switch & $\begin{array}{c}6.4952^{* * *} \\
(0.0020)\end{array}$ & $\begin{array}{c}9.2044^{* * *} \\
(0.0066)\end{array}$ & $\begin{array}{c}6.7528^{* * *} \\
(0.0020)\end{array}$ \\
\hline Constant & $\begin{array}{c}-3.5080^{* * *} \\
(0.0014)\end{array}$ & $\begin{array}{c}-4.2560^{* * *} \\
(0.0051)\end{array}$ & $\begin{array}{c}-4.3193^{* * *} \\
(0.0045)\end{array}$ \\
\hline Observations & 15,675 & 6,476 & 14,663 \\
\hline Deviance Inf. Crit. & 4628.785 & 1699.528 & 3269.662 \\
\hline
\end{tabular}


Table 7: Estimates of the electricity retailer switch determinants with only household covariates (HCP). Standard errors in parentheses

\begin{tabular}{|c|c|c|c|c|}
\hline & \multicolumn{4}{|c|}{ Dependent variable: } \\
\hline & \multicolumn{4}{|c|}{ Electricity_retailer_switch } \\
\hline & (1) & $(2)$ & $(3)$ & $(4)$ \\
\hline \multicolumn{5}{|l|}{ Household } \\
\hline Over65_CP & $\begin{array}{c}-0.256^{* * *} \\
(0.057)\end{array}$ & $\begin{array}{c}-0.252^{* * *} \\
(0.058)\end{array}$ & $\begin{array}{c}-0.258^{* * *} \\
(0.058)\end{array}$ & $\begin{array}{c}-0.254^{* * *} \\
(0.058)\end{array}$ \\
\hline Nb_members & $\begin{array}{c}0.181^{* * *} \\
(0.021)\end{array}$ & $\begin{array}{c}0.183^{* * *} \\
(0.021)\end{array}$ & $\begin{array}{c}0.181^{* * *} \\
(0.021)\end{array}$ & $\begin{array}{c}0.183^{* * *} \\
(0.021)\end{array}$ \\
\hline Inhab $<10000$ & $\begin{array}{c}0.077 \\
(0.071)\end{array}$ & $\begin{array}{c}0.085 \\
(0.071)\end{array}$ & $\begin{array}{c}0.083 \\
(0.071)\end{array}$ & $\begin{array}{c}0.092 \\
(0.071)\end{array}$ \\
\hline Inhab >10000 & $\begin{array}{l}-0.072 \\
(0.069)\end{array}$ & $\begin{array}{l}-0.069 \\
(0.069)\end{array}$ & $\begin{array}{l}-0.075 \\
(0.069)\end{array}$ & $\begin{array}{l}-0.073 \\
(0.069)\end{array}$ \\
\hline North-East & $\begin{array}{l}-0.115 \\
(0.077)\end{array}$ & $\begin{array}{l}-0.107 \\
(0.077)\end{array}$ & $\begin{array}{c}-0.094 \\
(0.080)\end{array}$ & $\begin{array}{l}-0.084 \\
(0.080)\end{array}$ \\
\hline Centre & $\begin{array}{c}0.021 \\
(0.079)\end{array}$ & $\begin{array}{c}-0.003 \\
(0.079)\end{array}$ & $\begin{array}{c}0.049 \\
(0.084)\end{array}$ & $\begin{array}{c}0.028 \\
(0.085)\end{array}$ \\
\hline South & $\begin{array}{c}-0.561^{* * *} \\
(0.078)\end{array}$ & $\begin{array}{c}-0.571^{* * *} \\
(0.078)\end{array}$ & $\begin{array}{c}-0.519^{* * *} \\
(0.090)\end{array}$ & $\begin{array}{c}-0.523^{* * *} \\
(0.091)\end{array}$ \\
\hline Islands & $\begin{array}{c}0.424^{* * *} \\
(0.087)\end{array}$ & $\begin{array}{c}0.398^{* * *} \\
(0.087)\end{array}$ & $\begin{array}{c}0.479^{* * *} \\
(0.105)\end{array}$ & $\begin{array}{c}0.460^{* * *} \\
(0.106)\end{array}$ \\
\hline Econ_resources & $\begin{array}{l}-0.065 \\
(0.051)\end{array}$ & $\begin{array}{l}-0.050 \\
(0.052)\end{array}$ & $\begin{array}{l}-0.063 \\
(0.051)\end{array}$ & $\begin{array}{l}-0.048 \\
(0.052)\end{array}$ \\
\hline Sat_info_level & & $\begin{array}{c}-0.175^{* * *} \\
(0.052)\end{array}$ & & $\begin{array}{c}-0.175^{* * *} \\
(0.052)\end{array}$ \\
\hline Gas_retailer_switch & $\begin{array}{c}3.680^{* * *} \\
(0.066)\end{array}$ & $\begin{array}{c}3.667^{* * *} \\
(0.066)\end{array}$ & $\begin{array}{c}3.676^{* * *} \\
(0.066)\end{array}$ & $\begin{array}{c}3.663^{* * *} \\
(0.066)\end{array}$ \\
\hline \multicolumn{5}{|l|}{ Market } \\
\hline W_CR3 & & & $\begin{array}{l}-0.060 \\
(0.065)\end{array}$ & $\begin{array}{l}-0.067 \\
(0.065)\end{array}$ \\
\hline Constant & $\begin{array}{c}-2.615^{* * *} \\
(0.095)\end{array}$ & $\begin{array}{c}-2.520^{* * *} \\
(0.100)\end{array}$ & $\begin{array}{c}-2.608^{* * *} \\
(0.095)\end{array}$ & $\begin{array}{c}-2.513^{* * *} \\
(0.100)\end{array}$ \\
\hline Observations & 18,448 & 18,244 & 18,448 & 18,244 \\
\hline Log Likelihood & $-5,616.710$ & $-5,553.786$ & $-5,616.277$ & $-5,553.256$ \\
\hline Akaike Inf. Crit. & $11,255.420$ & $11,131.570$ & $11,256.560$ & $11,132.510$ \\
\hline McFadden & 0.2818 & 0.2818 & 0.2809 & 0.2809 \\
\hline
\end{tabular}


Table 8: Methodological survey

\begin{tabular}{|c|c|c|c|c|c|}
\hline Title & Country & Data & Observations & $\begin{array}{l}\text { Units of } \\
\text { analysis }\end{array}$ & Methodology \\
\hline $\begin{array}{l}\text { Consumer behaviour in } \\
\text { restructured electricity markets } \\
\text { (Rowlands et al., 2004) }\end{array}$ & $\begin{array}{l}\text { Ontario } \\
\text { (Canada) }\end{array}$ & $\begin{array}{l}\text { Survey } \\
\text { data }\end{array}$ & 315 and 601 & $\mathrm{HCP}$ & $\begin{array}{l}\text { Mean ranking } \\
\text { Differences in } \\
\text { means }\end{array}$ \\
\hline $\begin{array}{l}\text { Understanding customer } \\
\text { switching behavior in a } \\
\text { liberalizing service market: an } \\
\text { exploratory study (Wieringa } \\
\text { and Verhoef, 2007) }\end{array}$ & $\begin{array}{l}\text { The } \\
\text { Netherlands }\end{array}$ & $\begin{array}{l}\text { Survey } \\
\text { data } \\
\text { Customer } \\
\text { database } \\
\text { data }\end{array}$ & 7268 & IN & $\begin{array}{l}\text { Principal } \\
\text { Component } \\
\text { Analysis } \\
\text { Logit model } \\
\text { Logit model } \\
\text { with } \\
\text { heterogeneity }\end{array}$ \\
\hline $\begin{array}{l}\text { Customer switching behavior in } \\
\text { service industries: an } \\
\text { exploratory study (Keaveney, } \\
\text { 1995) }\end{array}$ & $\begin{array}{l}\text { Not } \\
\text { specified }\end{array}$ & Interview & 526 & IN & $\begin{array}{l}\text { Descriptive } \\
\text { statistics } \\
\text { Critical incident } \\
\text { technique }\end{array}$ \\
\hline $\begin{array}{l}\text { Consumer governance in } \\
\text { electricity markets (Daglish, } \\
\text { 2016) }\end{array}$ & $\begin{array}{l}\text { New } \\
\text { Zealand }\end{array}$ & Meter data & 1897085 & $\mathrm{HCP}$ & $\begin{array}{l}\text { Conditional } \\
\text { Logit model }\end{array}$ \\
\hline $\begin{array}{l}\text { Understanding household } \\
\text { switching behavior in the retail } \\
\text { electricity market (Yang, 2014) }\end{array}$ & Denmark & $\begin{array}{l}\text { Online } \\
\text { data }\end{array}$ & 1022 & $\mathrm{HCP}$ & $\begin{array}{l}\text { Logit model } \\
\text { Principal } \\
\text { Component } \\
\text { Analysis } \\
\text { Multinomial } \\
\text { Logit model }\end{array}$ \\
\hline $\begin{array}{l}\text { Behavioral aspects of } \\
\text { regulation: a discussion on } \\
\text { switching and demand response } \\
\text { in Turkish electricity market } \\
\text { (Sirin and Gonul, 2016) }\end{array}$ & Turkey & $\begin{array}{l}\text { Survey } \\
\text { data }\end{array}$ & 113 & $\mathrm{HCP}$ & $\begin{array}{l}\text { Multiple } \\
\text { Correspondence } \\
\text { Analysis } \\
\text { Fixed and } \\
\text { random effects } \\
\text { panel data } \\
\text { analysis }\end{array}$ \\
\hline $\begin{array}{l}\text { Liberalization of a retail } \\
\text { electricity market: consumer } \\
\text { satisfaction and household } \\
\text { switching behavior in Japan } \\
\text { (Shin and Managi, 2017) }\end{array}$ & Japan & Survey & 49,805 & $\mathrm{HCP}$ & $\begin{array}{l}\text { Logit model } \\
\text { with clustered } \\
\text { errors }\end{array}$ \\
\hline $\begin{array}{l}\text { Consumer attitudes towards } \\
\text { switching supplier in three } \\
\text { deregulated markets (Gamble } \\
\text { et al., 2009) }\end{array}$ & Sweden & Survey & 458 & $\mathrm{HCP}$ & $\begin{array}{l}\text { Principal } \\
\text { component } \\
\text { analysis } \\
\text { OLS regression }\end{array}$ \\
\hline $\begin{array}{l}\text { Households' switching behavior } \\
\text { between electricity suppliers in } \\
\text { Sweden (Ek and Söderholm, } \\
2008 \text { ) }\end{array}$ & Sweden & Survey & 564 & $\mathrm{HCP}$ & Probit model \\
\hline $\begin{array}{l}\text { Consumer choice and } \\
\text { competition policy: a study of } \\
\text { UK energy markets (Giulietti, } \\
\text { Waterson, et al., 2014) }\end{array}$ & Uk & Survey & 692 & $\mathrm{HCP}$ & Probit model \\
\hline $\begin{array}{l}\text { Do consumers switch to the best } \\
\text { supplier? (Wilson and } \\
\text { Waddams Price, 2010) }\end{array}$ & Uk & Interview & $\begin{array}{l}373 \text { low } \\
\text { income } \\
2027\end{array}$ & HCP & Probit model \\
\hline $\begin{array}{l}\text { Rationality of supplier } \\
\text { switching in retail electricity } \\
\text { markets (Annala et al., 2013) }\end{array}$ & Finland & $\begin{array}{l}\text { Price Data } \\
\text { from } \\
\text { Finnish } \\
\text { Energy } \\
\text { Market } \\
\text { Authority }\end{array}$ & - & $\mathrm{HCP}$ & Descriptive \\
\hline $\begin{array}{l}\text { Why do more British } \\
\text { consumers not switch energy } \\
\text { suppliers? The role of } \\
\text { individual attitudes (He and } \\
\text { Reiner, 2015) }\end{array}$ & $\mathrm{Uk}$ & Survey & 1942 & $\mathrm{HCP}$ & Logit model \\
\hline
\end{tabular}


Continued from the previous page

\begin{tabular}{|c|c|c|c|c|c|}
\hline Title & Country & Data & Observations & $\begin{array}{l}\text { Unit of } \\
\text { analysis }\end{array}$ & Methodology \\
\hline $\begin{array}{l}\text { Retail competition in electricity } \\
\text { supply - survey results in North } \\
\text { Carolina (McDaniel and } \\
\text { Groothuis, 2012) }\end{array}$ & $\begin{array}{l}\text { North } \\
\text { Carolina }\end{array}$ & Survey & 729 & $\mathrm{HCP}$ & $\begin{array}{l}\text { Tobit model } \\
\text { ordered Logit } \\
\text { and Logit } \\
\text { model }\end{array}$ \\
\hline $\begin{array}{l}\text { Customer satisfaction: a } \\
\text { meta-analysis of the empirical } \\
\text { evidence (Szymanski and } \\
\text { Henard, 2001) }\end{array}$ & - & $\begin{array}{l}\text { Scientific } \\
\text { Articles }\end{array}$ & 50 & - & $\begin{array}{l}\text { correlations } \\
\text { OLS regression }\end{array}$ \\
\hline $\begin{array}{l}\text { Household electricity contract } \\
\text { and provider switching in the } \\
E U \text { (Schleich et al., 2017) }\end{array}$ & $\begin{array}{l}\text { France, } \\
\text { Germany, } \\
\text { Italy, } \\
\text { Poland, } \\
\text { Romania, } \\
\text { Spain, } \\
\text { Sweden, Uk }\end{array}$ & Survey & 11,000 & $\mathrm{HCP}$ & $\begin{array}{l}\text { Multinomial } \\
\text { Probit model }\end{array}$ \\
\hline $\begin{array}{l}\text { Contrasting the drivers of } \\
\text { switching intent and switching } \\
\text { behavior in contractual service } \\
\text { settings (Wirtz et al., 2014) }\end{array}$ & Asia & Survey & 2,485 & IN & $\begin{array}{l}\text { Factor analysis } \\
\text { Generalized } \\
\text { Linear Model }\end{array}$ \\
\hline $\begin{array}{l}\text { Retail competition in electricity } \\
\text { markets (Defeuilley, 2009) }\end{array}$ & - & - & - & - & Qualitative \\
\hline $\begin{array}{l}\text { Consumers' switching inertia } \\
\text { in a fictitious electricity } \\
\text { market (Gärling et al., 2008) }\end{array}$ & Sweden & Survey & 540 & $\mathrm{HCP}$ & $\begin{array}{l}\text { t-test for mean } \\
\text { differences }\end{array}$ \\
\hline $\begin{array}{l}\text { Power to choose? An analysis } \\
\text { of consumer inertia in the } \\
\text { residential electricity market } \\
\text { (Hortaçsu et al., 2015) }\end{array}$ & Texas & $\begin{array}{l}\text { Meter } \\
\text { Data }\end{array}$ & $3,729,919$ & $\mathrm{HCP}$ & $\begin{array}{l}\text { Logit and } \\
\text { Multinomial } \\
\text { Logit models }\end{array}$ \\
\hline $\begin{array}{l}\text { Analysing households } \\
\text { responsiveness towards } \\
\text { socioeconomic determinants of } \\
\text { residential electricity } \\
\text { consumption in Singapore (Loi } \\
\text { and Le Ng, 2018) }\end{array}$ & Singapore & $\begin{array}{l}\text { Energy } \\
\text { Market } \\
\text { Authority's } \\
\text { energy } \\
\text { statistics }\end{array}$ & - & $\mathrm{HCP}$ & $\begin{array}{l}\text { One-way fixed } \\
\text { effect } \\
\text { Fully modified } \\
\text { OLS regression }\end{array}$ \\
\hline $\begin{array}{l}\text { To switch or not to switch? } \\
\text { Understanding German } \\
\text { consumers' willingness to pay } \\
\text { for green electricity tariff } \\
\text { attributes (Sauthoff et al., 2017) }\end{array}$ & Germany & $\begin{array}{l}\text { Survey } \\
\text { Discrete } \\
\text { Choice Ex- } \\
\text { periment }\end{array}$ & 371 & $\mathrm{HCP}$ & $\begin{array}{l}\text { Generalized } \\
\text { multinomial } \\
\text { Logit model }\end{array}$ \\
\hline $\begin{array}{l}\text { Barriers to switching in retail } \\
\text { electricity markets: a regional } \\
\text { analysis of the Italian market } \\
\text { (Fontana et al., 2018) }\end{array}$ & Italy & $\begin{array}{l}\text { Survey } \\
\text { National } \\
\text { Institute of } \\
\text { Statistics }\end{array}$ & $\begin{array}{c}42,492 \\
\text { individuals } \\
17,940 \\
\text { households }\end{array}$ & $\mathrm{HCP}$ & Logit model \\
\hline $\begin{array}{l}\text { The role of attitudes and } \\
\text { marketing in consumer } \\
\text { behaviours in the British retail } \\
\text { electricity market (Flores and } \\
\text { Waddams Price, 2018) }\end{array}$ & UK & Survey & 2537 & $\mathrm{HCP}$ & Probit model \\
\hline
\end{tabular}


LaTeX Source Files
Click here to download LaTeX Source Files: FIN_latex.zip

LaTeX Source Files
Click here to download LaTeX Source Files: FIN_latex.zip Click here to download LaTeX Source Files: FIN latex.zip

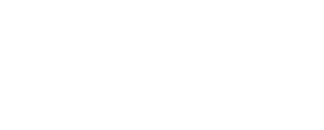

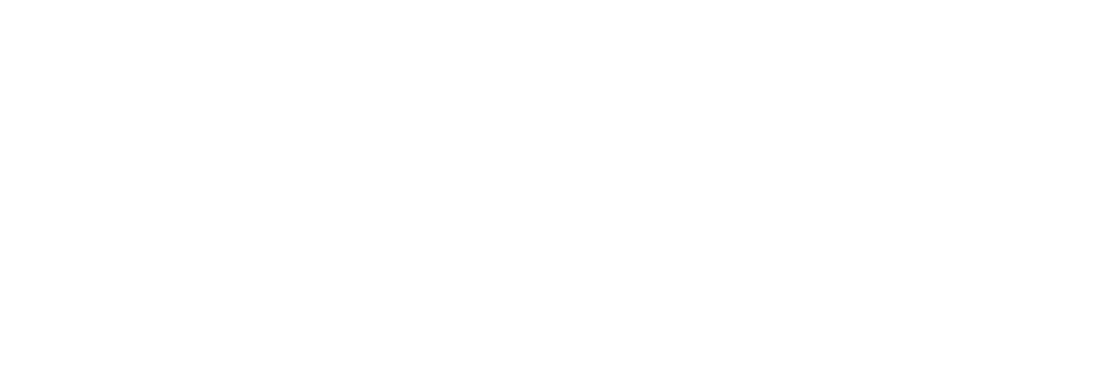

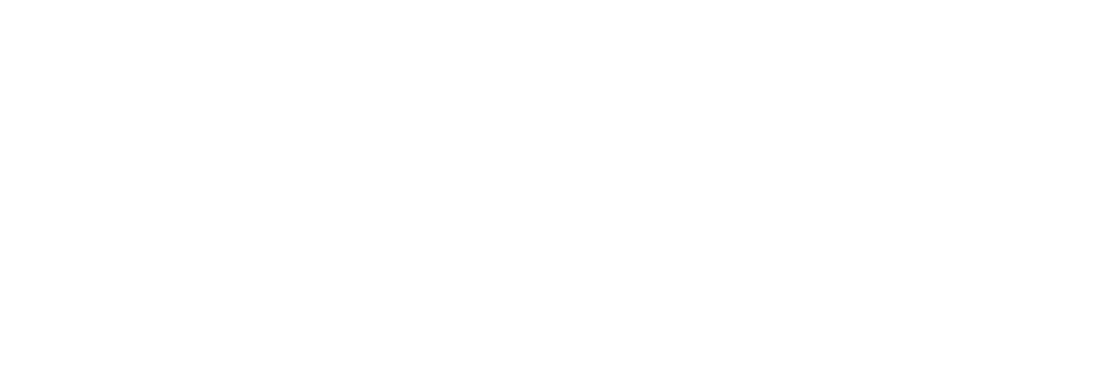

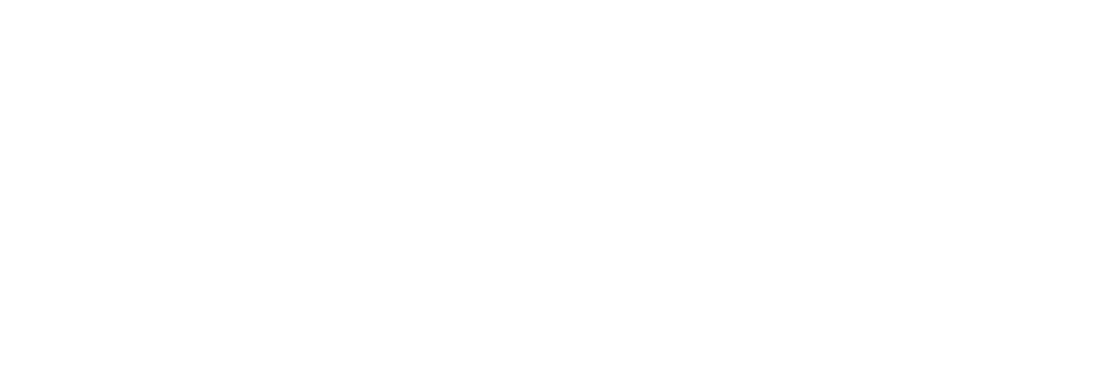

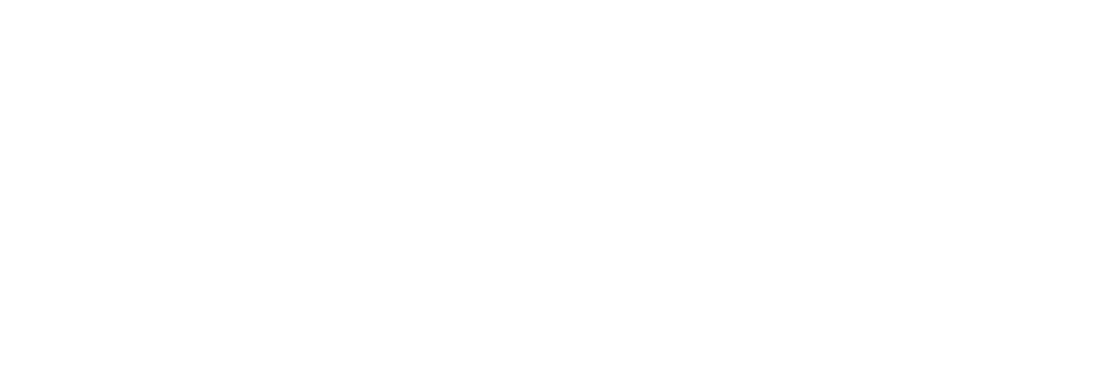

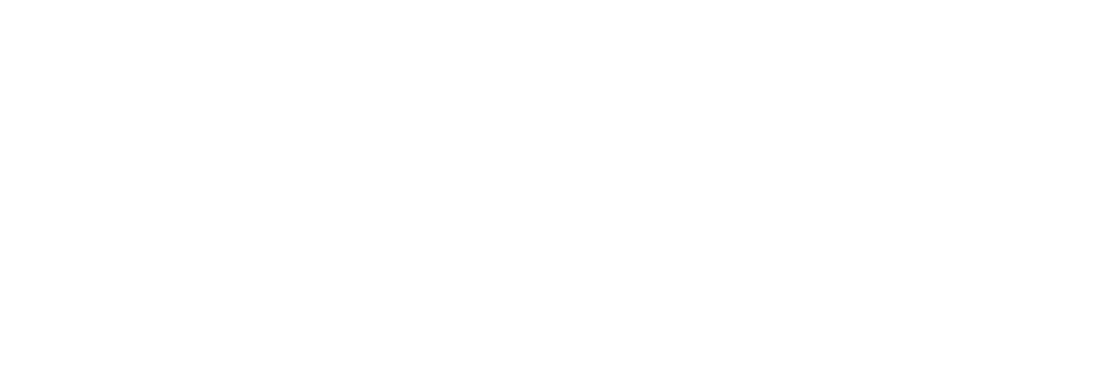

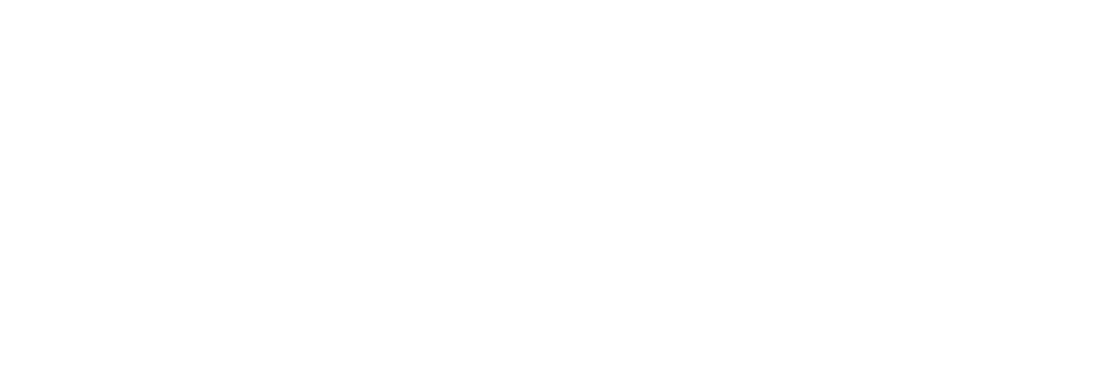

(1)

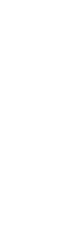

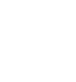

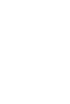

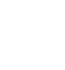

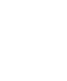

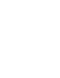

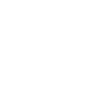

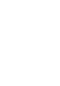

